Article

\title{
Employment Protection and Banking Power: Evidence from Adoption of Wrongful Discharge Laws
}

\author{
Desheng Yin ${ }^{1}$ and Xinting Zhen ${ }^{2, *(\mathbb{D})}$ \\ 1 School of Economics, East China Normal University, Shanghai 200062, China; dsyin@finance.ecnu.edu.cn \\ 2 Department of Business Administration and Accounting, Saint Michael's College, Colchester, VT 05439, USA \\ * Correspondence: xzhen@smcvt.edu; Tel.: +1-802-654-2904
}

\section{check for}

updates

Citation: Yin, D.; Zhen, X.

Employment Protection and Banking Power: Evidence from Adoption of

Wrongful Discharge Laws.

Sustainability 2021, 13, 1635.

https://doi.org/10.3390/su13041635

Academic Editor: Sajid Anwar

Received: 6 January 2021

Accepted: 29 January 2021

Published: 3 February 2021

Publisher's Note: MDPI stays neutral with regard to jurisdictional claims in published maps and institutional affiliations.

Copyright: (c) 2021 by the authors. Licensee MDPI, Basel, Switzerland. This article is an open access article distributed under the terms and conditions of the Creative Commons Attribution (CC BY) license (https:/ / creativecommons.org/licenses/by/ $4.0 /)$.

\begin{abstract}
Human capital and labor costs are crucial for the sustainable growth of organizations, and take a vital role in affecting bank efficiency and banking power. This research empirically investigates whether labor employment protection affects banking power. The analysis exploits the staggered adoption of Wrongful Discharge Laws (WDLs) as a quasi-exogenous shock to employment protection. A Difference-In-Difference research design is implemented to study the impacts of WDLs on banking power, and the main results show that there exists a decline of banking power for commercial banks headquartered in states that adopt employment protection. This study further tests the main mechanism through which WDLs affect banking power and finds that the impaired banking power is primarily due to cost inefficiency but not profit inefficiency. Moreover, the adoption of wrongful discharge laws increases commercial banks' labor costs and induces bank risk-taking.
\end{abstract}

Keywords: banking power; bank efficiency; wrongful discharge laws

\section{Introduction}

Bank market power has long been the focus of academics, policy makers, and practitioners [1]. Banking power, defined as the ability of a particular bank to charge a mark-up over its marginal cost [2], may affect the bank's sustainable development, increase the cost of financing for borrowing firms [3] and be responsible for a net loss of social welfare. High market power allows banks to charge prices in excess of the competitive level and creates a "comfort zone" for bank managers to enjoy the "quiet life" [2]. The quiet life hypothesis indicates that firms with market power prefer to operate inefficiently instead of reaping potential monopolistic rents. Such inefficiency that is related with high banking power could be driven by either cost inefficiency or profit inefficiency. Specifically, Berger and Hannan [2] present the quiet life hypothesis for US banks regarding their capability to operate at minimal cost, whereas Hicks [4] indicates that firms with market power prefer to forgo some of their potential profits. An important consequence of the inefficiency is that bank inefficiency is always associated with higher risks [5], and such risk-taking behavior affects financial and economic fragility [6-8].

Given that efficiency is important for the banking sector to withstand negative shocks and contributes to the sustainable growth and stability of the financial system [9], numerous scholars have investigated the negative relationship between bank market power and efficiency [2]. Particularly, Koetter, et al. [10] extend the literature by studying the simultaneous relation between market power and efficiency inherent in this tradeoff. To measure banking power, they estimate an efficiency-adjusted Lerner index, which simultaneously estimates cost and profit efficiency scores. Their evidence rejects the quiet life hypothesis for cost inefficiencies, but supports Hick's conjecture about the quiet life hypothesis for profit inefficiencies.

Labor costs as an important input in the production function to measure bank efficiency takes a vital role in affecting the efficiency score and ultimately, affecting banking power [10-12]. Due to the rise of employment protection regulation, the nature of these 
labor costs has shifted dramatically, and thus resulted in higher labor costs and greater potential employee litigation [13]. Considering that wage takes one of the largest portions of the cost of production for the average U.S. firms [14] and significantly affects corporate investment and managerial decisions, we anticipate that employment protection laws take an important role in affecting banking power when a bank faces larger labor costs. The underlying mechanism is as follows. Based on the conventional research [10], the measurement of banking power includes two components: cost efficiency and profit efficiency. Any factor that directly affects the efficiency scores would implicitly have impacts on banking power, and thus an increasing of labor costs due to shocks from the labor market as an important input factor should take a vital role in affecting the firm efficiency. Therefore, a possible channel through which employment protection may affect banking power is the cost or profit efficiency, or both efficiencies simultaneously.

The effect of employment protection on banking power is ambiguous ex-ante. It is possible that Employment protection laws may affect banking power in opposite ways. On the one hand, employment protection laws provide job security to incentivize employees to invest in their own human capital to improve efficiency and increase banking power consequently. On the other hand, as the employment protection increases the fixed costs that a firm has to pay independently of its performance [15], such regulations make employers reluctant to hire and result in a less flexible labor force within an organization and reduce banks' competitiveness, and thus lead to a reduction of banking power. Ultimately, whether employment protection by laws may affect bank market power through bank efficiency is an empirical question, which necessitates further investigation. This research attempts to answer these questions.

To address these research questions, in this article, the staggered adoption of Wrongful Discharge Laws (WDLs) is used as a quasi-natural shock to employment protection. Adopted by most U.S. state courts during the 1970's and 1980's, WDLs create three classes of common-law restrictions that limit employers' ability to fire [16]: the public policy, good faith, and implied contract exceptions. WDLs aim to protect employees against a legal presumption that an employee may be discharged by her employer for any reason [17]. The real economic effects of WDLs can be multi-fold. Autor, et al. [18] and David, et al. [19] indicate that, mandated employment protections, such as WDLs, reduce productivity by distorting production choices. Acharya, et al. [20] find that wrongful discharge laws increase firm innovation and spur entrepreneurship. MacLeod and Nakavachara [21] indicate that although wrongful discharge laws have either a negative or small effect on employment, one class of WDLs-good faith-has a positive effect for high investment occupations in the less populated areas. Importantly, the employment protection also affects corporate capital structure decision [15,22], tax aggressiveness [13], cash-holding decision [23], risk management [24], payout policies [25], and accounting conservatism [26].

The US banking industry is considered as a natural laboratory for studying the effects of wrongful discharge laws on banking power. Banks are relatively homogenous firms that are undiversified for the most part, which permits performance comparisons [27]. Therefore, to some extent, focusing on banking institutions can help rule out certain omitted factors that may bias the results. Particularly, the adoption of WDLs is used as a source of exogeneous shocks to investigate the real effect of employment protection laws on bank market power. The adoption of WDLs by different states in the U.S. presents an ideal setting for us to perform a natural experiment. First, the U.S. states have adopted these laws over various time periods, which allow us to isolate the effects of the laws from macro-economic conditions. Second, WDLs are common law exceptions and are made by judges in courts. Due to these characteristics, the WDLs are less likely to be influenced by lobbying than laws created through legislation [13,28]. Existing investigations $[22,29]$ also support that the passage of WDLs is exogenous to firm-level characteristics, because judicial decisions in precedent-setting cases are more likely to be driven by the merits of the individual cases than by political economy considerations. Third, in addition to financial capital, banks use extensively human capital to support their operations and long-term 
growth. As a critical intangible asset, human capital is a substantial part of the deliberate corporate investment [30-32], and plays a vital role in bank sustainability, competitiveness, and efficiencies [10]. Therefore, it is critical to investigate how the labor protection laws as a shock from the labor market affect bank competitive power.

This study asks the research question of whether and to what extent the labor protection law as an exogenous shock to a firm's firing costs may affect bank market power through affecting bank efficiency. The cross-state variation in the adoption of WDLs as a quasi-exogenous shock is exploited to examine the causal relation between employment protection and banking power. The analysis follows the conventional literature and focuses on the bank headquarters locations that employees are typically located. This research focuses on commercial banks and follows Lerner [1] and Koetter, et al. [10] to measure bank market power by using the adjusted Lerner index. A Difference-In-Difference research design is adopted to study the impact of WDLs on banking power, and the main results show that there exists a decline in banking power for banks headquartered in states that adopt the employment protection. This research further tests the main mechanism through which labor protection law affects banking power, and finds that the impaired banking power is primarily due to cost inefficiency but not profit inefficiency. Furthermore, the results show that the adoption of WDLs increases labor costs of the sample banks and increases bank risk-taking.

This research contributes to the bank efficiency literature. There exist voluminous investigations to discuss possible determinants of banking efficiency. Studies that attempt to investigate banking power and efficiency primarily focus on market structure, institutional factors, and regulatory changes [33-35], and bank-specific, market-specific, and macroeconomic determinants [36-39]. However, labor market frictions as potential sources of determinants of efficiency and banking power have largely been ignored. This study extends the current literature by mainly investigating employment protection laws as important determinants in affecting banking power.

This investigation also contributes to the existing work showing that employment laws can have a substantial effect on corporate capital structure, investment, various corporate policies, financial reporting, and risk management $[13,15,20,22-26,40]$. The main findings in this research complement these investigations by indicating that employment protection laws affect bank market power in addition to investment decisions, financial reporting, and corporate policies. One important implication from this study is that labor protection laws may impair bank market power through reducing bank cost efficiency.

In addition, this paper is also related to the literature examining the determinants of bank risks. In searching for possible explanations for what drives bank risk-taking, the current literature has examined various factors, such as industry competition [41,42], monetary policies [43], and regulatory policies [8,44]. Another relevant research [24] that relates the labor market frictions and risk management studies the effects of labor adjustment costs on corporate risk management, and document that one particular doctrine of wrongful discharge laws-the good-faith exception- has a significant impact on the use of foreign currency derivative contracts. This research differs from the above mentioned studies by mainly focusing on the banking industry and identifying a new economic channel through which employment protection laws affect bank overall risks. This paper empirically documents that WDLs increase bank overall risks through reducing bank efficiency, and the findings suggest that employment protection laws have important implications for bank risk-taking.

The rest of this paper is organized as follows: Section 2 introduces the institutional background of WDLs and provides a review of related literature. Section 3 details the data, sample, and measures. Section 4 reports empirical results, and Section 5 summarizes and concludes. 


\section{Background and Related Literature}

\subsection{Institutional Background of Wrongful Discharge Laws}

There had long been a legal presumption that workers could be fired at will in the U.S. until 1970s. However, during the 1970s and 1980s, the majority of U.S. state courts adopted one or more common-law exceptions to the employment-at-will doctrine that limited employers' ability to fire [18]. These common laws are created by state courts and are designed to protect workers from wrongful discharge. The legal profession of "wrongful discharge laws" (WDLs) distinguishes three distinct doctrines: the impliedcontract exception, the good-faith exception, and the public-policy exception.

According to Autor, et al. [18], the implied-contract exception is a WDL that comes into force when an employer implicitly promises not to terminate a worker without good cause. To the most updated, 41 states recognize the implied-contract exception. The good-faith exception applies when a court determines that an employer discharges an employee out of bad faith, retaliation, or malice. Between 1970 and 1999, 13 states have adopted the goodfaith exception. The public-policy exception assures that an employer cannot discharge an employee for refusing to commit an illegal act, performing a public obligation, exercising an employment right, or reporting on the employer's illegal behavior (whistleblowing). By 1999, 43 U.S. states recognized a public-policy exception. The WDLs may increase the number of lawsuits and legal liability the firm should face, given the fact that such labor protection laws motivate employers to bring more wrongful termination lawsuits [25].

This study summarizes the month and year when these three exceptions were passed by states in the Appendix A. The most common form of WDL is the public-policy exception (passed in 43 states), followed by the implied-contract (adopted by 43 states; two states later reversed the adoption) and good-faith exceptions (adopted by 13 states; two states later reversed the adoption) [29].

The three common law exceptions have varying degrees of recognition and application across states and differ in their legal and economic significance [18]. This study consider all three doctrines of WDLs and test their effects on banking power and bank efficiency separately.

\subsection{Related Literature}

Bank competition power matters for the sustainability of the banking sector [45], the systemic stability [46,47], bank failures [48], the efficiency of the production of financial services, the quality of financial services and external financing, and in turn affects overall economic growth [49]. Schaeck, et al. [47] state that more competitive banking systems are less prone to experience a systemic crisis. Similarly, existing literature indicate that banks with a higher degree of market power have less overall risk exposure, and regulatory policies and institutions that thwart competition are associated with greater banking system fragility [50,51]. Given the vital role bank competition power takes in affecting the growth of the banking industry, voluminous investigations have given attention to the bank market power, which has been regarded as an appropriate measurement of bank competition [51-53]. As proposed by Maudos and de Guevara [3], banking power is an important lender characteristic [1] and is closely related with bank efficiency. Such a close relationship further attracts great interests for researchers to analyze how banking power can affect bank efficiency [2]. Koetter, et al. [10] provide empirical evidence to show the simultaneous relation between banking power and bank efficiencies. Their findings provide consistent results with Hicks's [4] quiet life hypothesis that banks with high banking power may forgo monopolistic rents and incur profit inefficiencies. Along with this line of research, some additional investigations focus on the determinants of bank efficiency [38,39]. For instance, Girardone, et al. [37] find that bank inefficiency is inversely correlated with capital strength and positively related to the level of non-performing loans.

According to Pampurini and Quaranta [54], bank efficiency that characterizes the production process has a strong relationship with sustainability, which indicates competitive advantage, because banks involved in sustainability issues can improve their reputation 
and credibility. From a long-term perspective, bank cost and profit efficiency are one of the most important premises for sustainability, and such importance motivates researchers to measure the economic efficiency of different bank institutions [55]. Considering the important role bank efficiency takes in providing better service quality for consumers and maintaining the financial stability of the banking system [9], researchers have given particular attention in investigating the determinants of bank efficiency, including internal micro or bank-specific determinants of efficiency, and external industry-specific and macroeconomic determinants [36]. Particularly, as a vital input factor in the production function to measure efficiency and banking power, labor costs can have influential impacts on both the efficiency and banking power [10-12] and deserve further explorations.

Recently, in the finance literature, researchers are increasingly paying attention to employment protection laws, given that labor protection laws can have substantial influences on labor costs, and consequently affect labor economic and firm performance [18]. For instance, studies show that employment protection affects corporate capital structure and investments [14,15,22], takeovers and mergers [56], payout policies [25], accounting conservatism [26], risk management [24], corporate cash holdings [23], tax aggressiveness [13], cash-holding decision [23], and firm-level cost behavior [29]. While existing literature emphasizes the vital role of employment protection laws takes in affecting various corporate policies, market frictions as potential sources of determinants of bank efficiency and banking power have largely been ignored. This study aims to fill the gap of existing literature by showing empirical evidence on the effects of employment protection on banking power.

Wrongful discharge laws (WDLs), mainly act as an employment protection law, increase labor adjustment costs substantially by making layoffs more difficult $[19,57,58]$. Previous literatures apply the adoption of WDLs as an exogenous shock to indicate its influential impacts on firm behavior and various corporate policies [13,24,29], as well as firm innovations [20]. Some other studies investigate the "price" of labor protection and find that such job security regulations reduce hiring and firing, and reduce employment flows and firm entry rates $[18,19,59]$. Particularly, due to the characteristic of labor-capital intensity in the bank industry, the effectiveness with the adoption of labor protection laws have raised researchers' interests. For instance, Bird and Knopf [60] use a sample of commercial banks to test the effects of labor protections adoption on firm productivity. They indicate that dismissal protection can impose costs of efficiency and find that the adoption of implied contract significantly reduces firm productivity. This investigation intends to further the discussion of the effects of WDL on firm performance. Particularly, the analysis focuses on market power and efficiency at the individual bank level. This study extends the current literature by mainly investigating WDLs as important determinants in affecting banking power and bank efficiencies.

Moreover, this research is closely related with the work of Bird and Knopf [60]. By examining 18,000 commercial banks from 1977 to 1999, they investigate the relationship between wrongful discharge laws and bank performance and find that the adoption of wrongful-discharge laws increases labor expenses. However, the analysis in this research is different from theirs in several aspects. First, they are interested in the overall impact in the banking industry, and they conduct their analysis at the state level. This research analyzes the effects of WDLs on banking power at the individual commercial bank level, instead of looking at the overall impact at the state level. Second, while they mainly focus on the effect of WDLs on labor employment and profitability, this study puts emphasize on exploring the relationship between WDLs and banking power, bank efficiencies, and risks. Finally, this paper reevaluates the impacts of wrongful-discharge doctrines on employment and wages at individual commercial bank level by using richer data, and also uses a dynamic approach to test the transitory effect of the labor protection law. 


\section{Data, Sample, and Measures}

\subsection{Sample Selection}

This investigation mainly relies on the Call Report database provided by the Federal Reserve Bank of Chicago. This database provides a comprehensive balance sheet and income statement for both commercial banks and bank holding companies (BHCs). This research focuses on commercial banks but not BHCs mainly due to the insufficient information of BHCs in the early years. Moreover, commercial banks are more suitable than BHCs to investigate in this study because commercial banks provide consistent and detailed performance data, and would better reveal the effect of wrongful discharge laws [60]. The legal appendix of Autor et al. [18] is applied to identify the date when a state adopts a particular at-will exception and code wrongful-discharge laws for all states in the U.S. (see the Appendix A). The sample in this study ranges from 1976 to 2007, starting when the call reports begin to report information of commercial banks, and ending before the global financial crisis to avoid any biased results due to the severe structural shock to both employment protection and banking power. It is also noticeable that the sample period encompasses the years 1971-1999 in existing literature [29,61], and Serfling [22] uses a sample period of 1970-1995. To test the robustness of the main findings obtained from this study, a different time period (1976-1999) is also applied in the tests and the main findings continue to hold. Consistent with Bird and Knopf [60], this analysis eliminates observations that reported zero employees, zero salaries, or negative equity in the sample.

\subsection{Measures of Dependent Variables}

The main dependent variable in the baseline regression is banking power, which is captured by the adjusted Lerner index [10]. Banking power captures the degree of monopoly power and is reflected by a bank's capability of charging a markup over its marginal cost, which is also known as the Lerner index [1,2]. Lerner [1] calculates the Lerner index using the following formula: Lerner index $=\frac{A R-M C}{A R}$. In the banking context, as bank competition increases, Lerner index should converge to zero; as bank market power becomes greater, the measure rises to the theoretical limit of one [62].

Lerner index has several advantages in that it can be measured both at the individual bank level and during time. Some existing papers use the well-known Panzar and Rosse $\mathrm{H}$ statistic as a measure of market share or market concentration measures $[47,63]$. Compared to the traditional measures, the Lerner index does not depend on the geographical market information of the bank and can better capture the individual bank's competitive power. Therefore, the Lerner index is superior to other traditional measures of competition [34,64], and has become the standard measure of firm monopoly power and one of the most widely cited indexes in the discipline of economics [65].

Lerner index is composed of two main components, which are marginal costs (MC) and average revenues $(A R)$. The miscalculation of each component may yield to biased results. According to Berger and Humphrey [66], on the input side, given the similar scale product mix, the average costs are not in the same level for different banks, therefore the assumption of equal cost efficiency of technical change is not applied in the banking industry, and cost inefficiency arises. Similarly, on the output side, profit inefficiency arises when banks forgone profits, mainly due to inefficient bank management or sub-optimally employment of input factors [67]. To account for the possibility that a particular bank is not operating at its full cost or profit efficiency, this investigation follows the method proposed by Koetter et al. [10] and calculates the adjusted Lerner index to capture the banking power.

To obtain accurate banking power in the presence of cost inefficiency and profit inefficiency, this study follows Koetter et al. [10] to adopt a two-step procedure to calculate the efficiency-adjusted Lerner index for individual commercial banks. Specifically, this study firstly starts with the universe of banks recorded in the Bank Call Report, and a stochastic frontier analysis (SFA) is used to estimate bank marginal costs and average revenues [33]. Secondly, based on the results from the previous step, the efficiency-adjusted 
Lerner index is measured from frontier estimates of predicted profits, total operating costs, and marginal costs.

In the first step, consistent with the previous studies estimating bank Lerner index [10-12], the study specifies inputs and outputs according to the intermediation model. A bank's production function uses labor and physical capital to attract deposits, and the deposits are then used to fund loans and other earning assets. This research uses the production technology that specifies borrowed funds, labor, and capital as three main inputs in the production process to produce two outputs, which mainly include $y_{1}$ (total loans) and $y_{2}$ (total securities). Three input prices are derived: the price of fixed assets $w_{1}$ as capital expenditures to fixed assets; the price of labor $w_{2}$ as the ratio of personnel expenditures to total assets; the price of deposits $w_{3}$ as total interest expenses over total customer deposits. Moreover, a netput $\mathrm{z}$ is included (ratio of equity to total assets) because it can be used to fund loans and reflects different risk attitudes of banks $[10,39,68]$. The production function is based on an assumption that factor markets are complete, and the bank chooses factor quantities at given factor prices in order to supply a desired output. This study follows the conventional efficiency literature $[10,69]$ to estimate marginal costs by applying a translog total cost function for banks across time series and impose the linear homogeneity restriction in inputs prices:

$$
\begin{array}{r}
\operatorname{LogTOC}_{j t}=\alpha+\sum_{i=1}^{3} \beta_{i} \log w_{i j t}+ \\
\sum_{k=1}^{2} \delta_{k} \log y_{k j t}+\sum_{i=1}^{3}\left(\frac{\gamma_{i}}{2}\right)\left(\log w_{i j t}\right)^{2}+\tau \log z_{j t}+\sum_{i<p} \sum \theta_{i j} \log w_{i j t} \log w_{p j t} \\
+\sum_{k=1}^{2}\left(\frac{\tau_{k}}{2}\right)\left(\log y_{k j t}\right)^{2}+\frac{1}{2} k_{12} \log _{1 j t} \log y_{2 j t}+\sum_{i=1}^{3} \sum_{k=1}^{2} \partial_{k i} \log w_{i j t} \log y_{k j t} \\
+\sum_{p=1}^{2} \varphi_{p} T+\sum_{i=1}^{3} \omega_{i} \log w_{i j t} T+\sum_{k=1}^{2} \rho_{k} \log y_{k j t} T+\mu_{j t}+v_{j t}
\end{array}
$$

As Equation (1) shows, $T O C_{j t}$ indicates the total operating costs for bank $j$ at time $t$, $y_{k j t}$ represents the output factors $\mathrm{k}$ for bank $j$ at time $t$, and $w_{i j t}$ represents the input factors $i$ of bank $j$ at year $t$. T indicates a time trend to capture technical change. The disturbance term contains two components: $v_{j t}$ is random fluctuations, which is assumed to be i.i.d. normally distributed, whereas $u_{j t}$ is assumed to be i.i.d. with a half-normal distribution. $u_{j t}$ is denoted as systematic deviations from optimal costs due to inefficiency. In short, the term $u_{j t}$ represents a bank's efficiency, whereas $v_{j t}$ indicates a random error. We estimate Equation (1) using an SFA approach based on standard assumptions in the literature [70]. Under the same output condition, a bank's efficiency is estimated by comparing its actual costs to the minimum costs, which are the best-practice costs by using the estimates of efficiency factor $\exp \left(-u_{j t}\right)$. Marginal costs are derived directly from Equation (1) by taking the sum of the derivatives with respect to total loans $\left(y_{2 j t}\right)$ and total securities $\left(y_{1 j t}\right)$.

To measure average revenues in the Lerner index formula, this study applies the profit efficiency model presented by Humphrey and Pulley [71], given the assumption that a perfectly competitive market does not hold, and bank output prices and input factors are endogenous variables in the model. The profit efficiency model takes into account potential profit inefficiency and measures to what extent a bank generates maximum profits given certain outputs. The estimated profit function is similar to the cost functions, but instead, profit before tax (PBT) is used as the dependent variable in the translog Equation (1). Alternatively, compared with the total cost function, the disturbance is specified to be $v_{j t}-u_{j t}$, representing profits below the best performance frontier levels.

In the second step, the efficiency adjusted Lerner index is obtained from the cost and profit function. Then Lerner index can be computed by using average revenues and marginal costs. To calculate the efficiency-adjusted Lerner index, the formula can be rewritten by using predicted total operating costs (TOC), corresponding marginal costs $(M C)$, profit before tax $(P B T)$, and total outputs $(T O)$ that summed by total loans and total securities. The efficiency-adjusted Lerner index can be expressed as: 
Adjusted Lerner index $=\frac{A R-M C}{A R}=\frac{\left(\frac{P B T}{T O}+\frac{T O C}{T O}\right)-M C}{\frac{P B T}{T O}+\frac{T O C}{T O}}=\frac{P B T+T O C-M C \times T O}{P B T+T O C}$

The "Adjusted Lerner index" is used in this study as the measure of banking power. As two main components of banking power, Cost efficiency and Profit efficiency are calculated simultaneously when we calculate the adjusted Lerner index. Compared with the traditional Lerner index, the adjusted Lerner index reflects the true condition that there exist cost inefficiency and profit inefficiency in the banking industry, thus provides a more accurate measurement of bank market power. In addition, this approach allows for individual bank's market power to evolve over time [3].

\subsection{Main Explanatory Variables}

Unlike federal antidiscrimination laws, which apply to all 50 states, wrongful discharge laws are products of state law. Autor, Donohue III, and Schwab [18] use the cross-state overtime adoption of wrongful discharge laws to measure how wrongful discharge laws impact earnings in state labor markets and employment levels. Similar to the investigations of Autor, et al. [18] and Kim, et al. [29], this study classifies a bank-year as a post-WDL year if the bank's calendar year falls after the bank's headquartered state adopts the WDL adoption but before the year the WDL is reversed, if a reversal had occurred. A set of dummy variables is defined for each of the laws. Those dummy variables, denoted as implied contract, public policy, and good faith, respectively, equal to one after the banks' headquarters are located in the state that adopts the particular policy in a given year and zero otherwise.

\subsection{Control Variables}

Existing literatures $[10,72]$ are reviewed to include a set of controls that captures various bank characteristics. Bank size is measured as the natural logarithm of bank total assets; MS is measured as a share of each bank's total assets with respect to aggregate assets per state in each year; SEC is measured as the share of securities of total assets; HHI loan is Herfindahl-Hirschman Index (HHI) of each bank's asset portfolio; TOP is an indicator variable that equals to one if the bank is among the 100 largest banks measured in total assets in the country in a given year, and zero otherwise. In addition, to consider the possibility that restrictions on employees from joining a rival company may affect the main analysis, this study also controls for the noncompetition enforceability index, which captures how well firms can bind employees [40]. The index is denoted as the Enforceability index that ranges from 0 to 9 , with 0 indicating the lowest enforcement and 9 indicating the highest enforcement. The analysis includes GDP per capita as the state-level control variable $[14,61]$. Moreover, due to the fact that banking operations are heavily regulated and subject to a series of deregulation changes $[60,73]$, two dummy variables are included to proxy for bank deregulation: Inter dummy is a dummy variable equal to 1 in the year and thereafter when the state entered an interstate banking agreement with another state, whereas Intra dummy is an indicator variable equal to 1 in the year and thereafter when the intrastate banking was allowed by means of mergers and acquisitions $[10,74]$.

\subsection{Summary Statistics}

Table 1 reports the summary statistics of variables used in regression analysis (see Panel A) and the correlation table (see Panel B). To avoid extreme values and possible outlier problem, a $99 \%$ winsorization for all variables is performed. The sampling procedure shows 325,545 bank-year observations, with 20,303 unique commercial banks. This study follows the conventional research and uses headquarters locations because employees are typically located in the headquarters state $[13,19]$. 
Table 1. Summary Statistics.

\begin{tabular}{|c|c|c|c|c|c|c|c|c|c|c|c|c|c|}
\hline \multicolumn{14}{|c|}{ Panel A. Descriptive Statistics } \\
\hline \multicolumn{2}{|c|}{ Variable } & \multicolumn{2}{|c|}{$\mathbf{N}$} & \multicolumn{2}{|c|}{ Mean } & \multicolumn{3}{|c|}{ Standard Deviation } & \multicolumn{2}{|c|}{ P25 } & P50 & \multicolumn{2}{|c|}{ P75 } \\
\hline \multirow{2}{*}{\multicolumn{2}{|c|}{$\begin{array}{l}\text { Adjusted Lerner index } \\
\text { Profit efficiency }\end{array}$}} & \multicolumn{2}{|c|}{325,545} & \multicolumn{2}{|c|}{0.4035} & \multicolumn{3}{|c|}{0.1039} & \multicolumn{2}{|c|}{0.3299} & 0.3961 & \multicolumn{2}{|c|}{0.4789} \\
\hline & & \multirow{2}{*}{\multicolumn{2}{|c|}{$\begin{array}{l}325,545 \\
325,545\end{array}$}} & \multicolumn{2}{|c|}{0.8918} & \multirow{2}{*}{\multicolumn{3}{|c|}{0.0341}} & \multirow{2}{*}{\multicolumn{2}{|c|}{0.8743}} & 0.8979 & \multicolumn{2}{|c|}{0.9161} \\
\hline & & & \multirow{2}{*}{\multicolumn{2}{|c|}{$\begin{array}{l}0.8238 \\
0.6463\end{array}$}} & & \multirow{2}{*}{\multicolumn{2}{|c|}{$\begin{array}{l}0.0823 \\
0.4781\end{array}$}} & & 0.7844 & 0.8428 & \multicolumn{2}{|c|}{0.8827} \\
\hline \multicolumn{2}{|c|}{ Implied contract } & \multicolumn{2}{|c|}{$\begin{array}{l}325,545 \\
325,545\end{array}$} & & & & & & \multicolumn{2}{|c|}{0} & 1 & 1 & \\
\hline Good & faith & 325 & & & & & 0.2606 & & & & 0 & 0 & \\
\hline Public & policy & 325 & & & & & 0.4662 & & & & 1 & 1 & \\
\hline Bank & size & 325 & & & & & 1.1857 & & & & 10.8024 & $11.61 \mathrm{~s}$ & \\
\hline $\mathrm{M}$ & & 325 & & & & & 0.2393 & & & & 0.0846 & 0.206 & \\
\hline $\mathrm{SE}$ & & 325 & & & & & 13.8895 & & & & 26.5887 & 36.637 & \\
\hline $\mathrm{HHI}$ & Joan & 325 & & & & & 0.1955 & & & & 0.7775 & 0.980 & \\
\hline Enforceabi & ity index & 325 & & & & & 1.7664 & & & & 5 & 6 & \\
\hline GDP p & capita & 325 & & & & & 10,630 & & & & 24,595 & 32,51 & \\
\hline Inter $\mathrm{d}$ & Immy & 325 & & & & & 0.4886 & & & & 1 & 1 & \\
\hline Intra $\mathrm{d}$ & Immy & 325 & & & & & 0.4887 & & & & 1 & 1 & \\
\hline & & & & & & Panel B. C & rrelations & & & & & & \\
\hline & $\begin{array}{l}\text { Adjusted } \\
\text { Lerner } \\
\text { Index }\end{array}$ & $\begin{array}{c}\text { Profit } \\
\text { Efficiency }\end{array}$ & $\begin{array}{c}\text { Cost } \\
\text { Efficiency }\end{array}$ & $\begin{array}{l}\text { Implied } \\
\text { Contract }\end{array}$ & Good Faith & $\begin{array}{l}\text { Public } \\
\text { Policy }\end{array}$ & Bank Size & MS & SEC & HHI Loan & TOP & $\begin{array}{l}\text { Enforceability } \\
\text { Index }\end{array}$ & $\begin{array}{l}\text { GDP per } \\
\text { Capita }\end{array}$ \\
\hline $\begin{array}{l}\text { Adjusted } \\
\text { Lerner } \\
\text { index }\end{array}$ & 1 & & & & & & & & & & & & \\
\hline $\begin{array}{c}\text { Cost } \\
\text { efficiency }\end{array}$ & $0.2080^{* * *}$ & $-0.2790^{* * *}$ & 1 & & & & & & & & & & \\
\hline $\begin{array}{l}\text { Implied } \\
\text { contract }\end{array}$ & $-0.1790 * * *$ & $-0.0083^{* * *}$ & $-0.0370^{* * *}$ & 1 & & & & & & & & & \\
\hline Good faith & $-0.0430 * * *$ & $-0.1040 * * *$ & $-0.0706^{* * *}$ & $0.1190 * * *$ & 1 & & & & & & & & \\
\hline $\begin{array}{l}\text { Public } \\
\text { policy }\end{array}$ & $-0.167^{* * *}$ & $0.0218^{* * *}$ & $0.0311^{* * *}$ & $0.5550 * * *$ & $0.1350 * * *$ & 1 & & & & & & & \\
\hline Bank size & $-0.0211 * * *$ & $0.0748^{* * *}$ & $-0.0292 * * *$ & $0.1310^{* * *}$ & $0.1270^{* * *}$ & $0.1720^{* * *}$ & 1 & & & & & & \\
\hline MS & $0.0201 * * *$ & $0.0600^{* * *}$ & $-0.0149^{* * *}$ & $-0.0165^{* * *}$ & $0.0640^{* * *}$ & -0.0025 & $0.5980 * * *$ & 1 & & & & & \\
\hline SEC & $-0.0135^{* * *}$ & $-0.0300 * * *$ & $0.1240^{* * *}$ & $0.0336^{* * *}$ & $-0.1340^{* * *}$ & $0.0230^{* * * *}$ & $-0.1280 * * *$ & $-0.0749^{* * *}$ & & & & & \\
\hline HHI Loan & $-0.0290^{* * *}$ & $0.0892^{* * *}$ & $-0.1040^{* * *}$ & $-0.1400^{* * *}$ & $0.0731 * * *$ & $-0.0995^{* * *}$ & $-0.0196^{* * *}$ & $-0.1120^{* * *}$ & $-0.1520 * * *$ & 1 & & & \\
\hline TOP & $-0.0118^{* * *}$ & $0.0096^{* * *}$ & 0.0050 ** & $-0.0053^{* *}$ & $0.0280^{* * *}$ & $-0.0047^{* *}$ & $0.3090^{* * *}$ & 0.2760 *** & $-0.0615^{* * *}$ & $-0.0340 * * *$ & 1 & & \\
\hline $\begin{array}{l}\text { Enforceability } \\
\text { index }\end{array}$ & $-0.0180 * * *$ & $0.0531^{* * *}$ & $0.1070^{* * *}$ & $-0.2450 * * *$ & $-0.3280^{* * *}$ & $-0.0852^{* * *}$ & $-0.0145^{* * *}$ & $-0.1150 * * *$ & $0.0632 * * *$ & $0.0074^{* * *}$ & $-0.0102 * * *$ & 1 & \\
\hline $\begin{array}{l}\text { GDP per } \\
\text { capita }\end{array}$ & $0.2220 * * *$ & $0.0391^{* * *}$ & $0.0108^{* * *}$ & $0.3110^{* * *}$ & $0.1180^{* * *}$ & $0.3050^{* * *}$ & $0.3530 * * *$ & $-0.0258^{* * *}$ & $-0.1530^{* * *}$ & $-0.0536^{* * *}$ & $0.0345^{* * *}$ & $-0.0477^{* * *}$ & 1 \\
\hline
\end{tabular}




\section{Empirical Results}

\subsection{Wrongful Discharge Laws and Banking Power}

Main regression analysis is conducted by examining the impact of wrongful discharge laws on banking power. A Difference-In-Difference (DID) analysis is performed to explain the effects of WDLs on banking power after the adoption of each exception on employment by state. The DID approach with the bank and high dimensional fixed effects can alleviate the heterogeneity problems raised by time-invariant unobserved bank characteristics and time-varying unobserved factors across states and regions. This treatment-control contrast identifies the causal effect of the exceptions on the outcomes of interest under the assumption that these outcomes would have otherwise evolved similarly in adopting and non-adopting states. To ensure that information of banks are available in the pre- and postperiod of the adoption of WDLs, the sample is restricted to a bank-year sample spanning two one-year periods before and after the adoption of WDLs (i.e., a 5-year window). The adjusted Lerner index is then modeled as a function of the adoption of WDLs, along with control variables capturing various bank characteristics, non-competition laws, as well as other state-level control variables. The DID strategy is implemented to analyze the effect of each three doctrines of WDLs on banking power by estimating the following equation:

$$
\text { Adjusted Lerner index } i_{i k t}=\alpha W D L_{k t}+\beta X_{i k t}+\delta_{t}+\delta_{i}+\delta_{r} \times \delta_{t}+\varepsilon_{i k t}
$$

where $i$ indexes banks, $k$ indexes states, and $t$ indexes time. $W D L_{k t}$ includes three main wrongful discharge laws in state $\mathrm{k}$ at time $\mathrm{t}$ respectively: Implied contract, Good faith, and Public policy. All specifications include year fixed effects $\delta_{t}$ and bank fixed effects $\delta_{i}$. The bank fixed effects absorb bank shocks that may be correlated across states. The year fixed effects control for the inter-temporal technological shocks and reduce the possibility of finding a spurious relationship due to a missing smooth trend variable or a specific annual shock. The analysis also includes interactions between four Census-region dummies and individual calendar year dummies $\left(\delta_{r} \times \delta_{t}\right)$ to absorb the regional shocks [18]. $X_{i k t}$ includes a series of control variables for each bank $i$ in state $k$ at time $t$. The Huber-White standard errors clustered on banks are reported.

Table 2 reports the results of difference-in-difference estimates based on Equation (3), to show the impacts of the adoption of WDLs by state on individual commercial bank's banking power in affected states. To test the robustness of the main findings, the analysis is also conducted based on different time periods. Columns 1-3 report main results based on the main data sampling period 1976-2006, whereas columns 4-5 report results based on the sample period 1971-1999, which are applied in existing literature $[29,61]$.

The effects of implied contract, good faith, and public policy on banking power are examined and reported in columns 1-3, respectively, after controlling for bank and year fixed effects. Although the effect of good faith on banking power is insignificant, consistent results for the rest two exceptions are found: implied contract and public policy. For a robustness check, tests based on a 3-year window are also conducted and consistent results are found. The estimated coefficient of implied contract in column 1 implies that the bank experiences a reduction of banking power by 0.0029 after its headquartered state adopted the implied contract exception. Similarly, in column 3, public policy enters with a coefficient of -0.0019 indicating that banking power decreases by about 0.0019 after the bank's headquartered state passed the public policy exception, holding other factors constant. Thus, the estimates in Table 2 indicate that the adoption of implied contract exception and public policy exception, on average, induced a $0.72 \%$ reduction and a $0.47 \%$ reduction in banking power, respectively. Similar results are found in columns 4-6, showing that the main results continue to hold based on a different sampling period. Particularly, the coefficient of good faith shows negative and significant in column 5, indicating that the effect of good faith on banking power is more pronounced in the sample period 1976-1999 than in the main sample period. However, the main results do not alter in a significant way except for this minor change. The coefficients of both implied contract and public policy 
are still significantly negative in columns 4 and 6 , showing that the overall effects of WDLs on banking power are negative. These findings lead to the conclusion that the adoption of WDLs have significant impacts on banking power $(p<0.01)$.

Table 2. The effects of wrongful discharge laws on banking power.

\begin{tabular}{|c|c|c|c|c|c|c|}
\hline \multirow[t]{3}{*}{ Independent Variables } & \multicolumn{6}{|c|}{ Dependent Variable: Adjusted Lerner Index } \\
\hline & \multicolumn{3}{|c|}{ Data Sample Period: 1976-2006 } & \multicolumn{3}{|c|}{ Data Sample Period: 1976-1999 } \\
\hline & (1) & (2) & (3) & (4) & (5) & (6) \\
\hline Implied contract & $\begin{array}{c}-0.0029 * * * \\
{[0.0009]}\end{array}$ & & & $\begin{array}{c}-0.0038^{* * *} \\
{[0.0009]}\end{array}$ & & \\
\hline Good faith & & $\begin{array}{l}-0.0014 \\
{[0.0019]}\end{array}$ & & & $\begin{array}{c}-0.0053^{* * *} \\
{[0.0019]}\end{array}$ & \\
\hline Public policy & & & $\begin{array}{c}-0.0019 * * \\
{[0.0009]}\end{array}$ & & & $\begin{array}{c}-0.0026^{* * * *} \\
{[0.0009]}\end{array}$ \\
\hline Bank size & $\begin{array}{c}-0.0079 * * * \\
{[0.0012]}\end{array}$ & $\begin{array}{l}-0.0014 \\
{[0.0010]}\end{array}$ & $\begin{array}{c}-0.0074^{* * *} \\
{[0.0011]}\end{array}$ & $\begin{array}{c}-0.0118^{* * *} \\
{[0.0014]}\end{array}$ & $\begin{array}{c}-0.0053^{* * *} \\
{[0.0011]}\end{array}$ & $\begin{array}{c}-0.0103^{* * *} \\
{[0.0013]}\end{array}$ \\
\hline MS & $\begin{array}{l}0.0075 * \\
{[0.0042]}\end{array}$ & $\begin{array}{c}0.0039 \\
{[0.0037]}\end{array}$ & $\begin{array}{c}0.0019 \\
{[0.0043]}\end{array}$ & $\begin{array}{c}0.0261^{* * *} \\
{[0.0054]}\end{array}$ & $\begin{array}{c}0.0191^{* * *} \\
{[0.0047]}\end{array}$ & $\begin{array}{c}0.0189 * * * \\
{[0.0055]}\end{array}$ \\
\hline SEC & $\begin{array}{l}0.0001^{* *} \\
{[0.0000]}\end{array}$ & $\begin{array}{c}0.0001^{* * *} \\
{[0.0000]}\end{array}$ & $\begin{array}{c}0.0001^{* * *} \\
{[0.0000]}\end{array}$ & $\begin{array}{c}0.0000 \\
{[0.0000]}\end{array}$ & $\begin{array}{l}0.0001 * * \\
{[0.0000]}\end{array}$ & $\begin{array}{c}0.0001^{* * *} \\
{[0.0000]}\end{array}$ \\
\hline HHI loan & $\begin{array}{c}-0.0153^{* * *} \\
{[0.0021]}\end{array}$ & $\begin{array}{c}-0.0176^{* * *} \\
{[0.0018]}\end{array}$ & $\begin{array}{c}-0.0093^{* * *} \\
{[0.0022]}\end{array}$ & $\begin{array}{c}-0.0181 \text { *** } \\
{[0.0023]}\end{array}$ & $\begin{array}{c}-0.0201 * * * \\
{[0.0021]}\end{array}$ & $\begin{array}{c}-0.0092^{* * * *} \\
{[0.0024]}\end{array}$ \\
\hline TOP & $\begin{array}{c}0.0285^{* * *} \\
{[0.0033]}\end{array}$ & $\begin{array}{c}0.0196 \text { *** } \\
{[0.0030]}\end{array}$ & $\begin{array}{c}0.0287 * * * \\
{[0.0035]}\end{array}$ & $\begin{array}{c}0.0240 * * * \\
{[0.0036]}\end{array}$ & $\begin{array}{c}0.0191^{* * *} \\
{[0.0033]}\end{array}$ & $\begin{array}{c}0.0250 * * * \\
{[0.0038]}\end{array}$ \\
\hline Enforceability index & $\begin{array}{c}0.0033^{* * *} \\
{[0.0009]}\end{array}$ & $\begin{array}{c}0.0023^{* * *} \\
{[0.0008]}\end{array}$ & $\begin{array}{c}0.0030^{* * *} \\
{[0.0009]}\end{array}$ & $\begin{array}{c}0.0040 * * * \\
{[0.0010]}\end{array}$ & $\begin{array}{c}0.0026^{* * *} \\
{[0.0010]}\end{array}$ & $\begin{array}{c}0.0034^{* * *} \\
{[0.0010]}\end{array}$ \\
\hline GDP per capita & $\begin{array}{c}0.0000 * * * \\
{[0.0000]}\end{array}$ & $\begin{array}{c}0.0000^{* * *} \\
{[0.0000]}\end{array}$ & $\begin{array}{c}0.0000^{* * *} \\
{[0.0000]}\end{array}$ & $\begin{array}{c}0.0000^{* * *} \\
{[0.0000]}\end{array}$ & $\begin{array}{c}0.0000^{* * * *} \\
{[0.0000]}\end{array}$ & $\begin{array}{c}0.0000^{* * *} \\
{[0.0000]}\end{array}$ \\
\hline Inter dummy & $\begin{array}{c}0.0053^{* * *} \\
{[0.0008]}\end{array}$ & $\begin{array}{c}0.0084^{* * *} \\
{[0.0008]}\end{array}$ & $\begin{array}{c}0.0049^{* * *} \\
{[0.0009]}\end{array}$ & $\begin{array}{c}0.0053^{* * * *} \\
{[0.0009]}\end{array}$ & $\begin{array}{c}0.0084^{* * *} \\
{[0.0008]}\end{array}$ & $\begin{array}{c}0.0041^{* * *} \\
{[0.0009]}\end{array}$ \\
\hline Intra dummy & $\begin{array}{c}0.0000 \\
{[0.0009]}\end{array}$ & $\begin{array}{c}0.0036^{* * *} \\
{[0.0008]}\end{array}$ & $\begin{array}{c}0.0011 \\
{[0.0009]}\end{array}$ & $\begin{array}{l}-0.0013 \\
{[0.0009]}\end{array}$ & $\begin{array}{c}0.0032 * * * \\
{[0.0008]}\end{array}$ & $\begin{array}{l}-0.0003 \\
{[0.0009]}\end{array}$ \\
\hline Constant & $\begin{array}{c}0.5826^{* * *} \\
{[0.0180]}\end{array}$ & $\begin{array}{c}0.5288^{* * *} \\
{[0.0163]}\end{array}$ & $\begin{array}{c}0.5008^{* * *} \\
{[0.0117]}\end{array}$ & $\begin{array}{c}0.4091^{* * * *} \\
{[0.0226]}\end{array}$ & $\begin{array}{c}0.3411^{* * *} \\
{[0.0210]}\end{array}$ & $\begin{array}{c}0.4416^{* * *} \\
{[0.0143]}\end{array}$ \\
\hline Bank fixed effects & Yes & Yes & Yes & Yes & Yes & Yes \\
\hline Year fixed effects & Yes & Yes & Yes & Yes & Yes & Yes \\
\hline Region $\times$ Year dummies & Yes & Yes & Yes & Yes & Yes & Yes \\
\hline Observations & 230,516 & 308,443 & 217,042 & 191,808 & 252,733 & 179,750 \\
\hline Adjusted R-squared & 0.6631 & 0.6510 & 0.6602 & 0.4758 & 0.4638 & 0.4688 \\
\hline
\end{tabular}

$*, * * * * *$ indicate significance levels at $10 \%, 5 \%$, and $1 \%$, respectively.

In the baseline regressions, several bank characteristics that could impact the results are controlled. For instance, bank size is included, and a dummy variable, TOP, is also included, to control for the largest 100 banks based on total asset and thus to rule out the big bank effects. The coefficients of TOP are all significantly positive $(p<0.01)$, showing that large banks are more likely to have higher banking power than other banks. Besides, the main results indicate that in contrast to the WDLs, the Enforceability index shows a positive and significant relationship with banking power $(p<0.01)$, indicating that banks have higher banking power if they are better at binding their employees. Not surprisingly, more favorable GDP per capital and bank deregulation both significantly increase banking power $(p<0.01)$. In conclusion, the main results are held after bank characteristics, bank deregulation, state economic factor, and noncompetition enforceability index are all controlled. This empirical evidence is in line with the notion that managers who are implicated by wrongful discharge complaints are more likely to suffer diminished career advancement, lower performance ratings, and higher turnover rates, therefore experience a reduction of firm competition power [75]. 


\subsection{Pre-Treatment Analysis and Dynamic Effects of WDLs on Banking Power}

To evaluate the validity of the DID approach that the passage of WDLs is exogenous, and test the assumption of the DID method that banks that adopt WDLs do not follow the parallel pre-existing trends, this study estimates the pre-treatment effects to investigate the dynamic effects of WDLs on banking power [61]. In this section, the pre-treatment and dynamic effects of WDLs on banking power are tested by decomposing the passage of the WDLs into four different time periods: one year before the passage of the WDLs, one year, two years, and three years after the passage of the WDLs.

The results of pre-treatment and dynamic effects are reported in Table 3. Columns 1-4 focus on implied contract, columns 5-8 focus on good faith, and columns 9-12 focus on public policy. In columns 1,5 , and 8 , the effects of good faith and public policy on adjusted Lerner index $t_{t-1}$ are both insignificant, except for implied contract, which shows a negative result. This one exception only does not affect the overall results, and therefore, taken together, WDLs are not significantly associated with banking power one year before the passage of the laws. These findings prove that there exists little evidence of the pre-treatment effect, and show that the parallel trends assumption of DID approach is satisfied. The coefficients of WDLs on adjusted Lerner index $t_{t+1}$, adjusted Lerner index $t+2$ and adjusted Lerner index $t_{t+3}$ are generally all negative and highly significant $(p<0.01)$, indicating that the passage of WDLs reduces banking power not only in the current period, but also in the following one, two and three years. Overall, the results of pre-treatment and dynamic effects provide evidence to support the main findings that WDLs significantly reduce banking power.

\subsection{Profit Efficiency and Cost Efficiency: Which One Gets Hurt?}

Considering that banking power can be decomposed of two main components: cost efficiency and profit efficiency, this study investigates how the reduction effect of WDLs on banking power can be contributed to each of the components. To uncover which component of banking power is affected by the adoption of WDLs, this study further investigates the effect of WDLs on bank profit efficiency and cost efficiency, respectively.

The results of the effect of wrongful discharge laws on bank efficiencies are reported in Table 4. Columns 1, 2, and 3 report the results when the dependent variable is profit efficiency. Insignificant coefficient estimates of good faith and public policy are observed, respectively. Although the coefficient of an implied contract is significant at the $10 \%$ level, the magnitude is relatively small, so it can be concluded that the overall effects of WDLs on profit efficiency are insignificant. The results indicate that the reduction of banking power caused by WDLs is not due to profit inefficiency. 
Table 3. Dynamic effects.

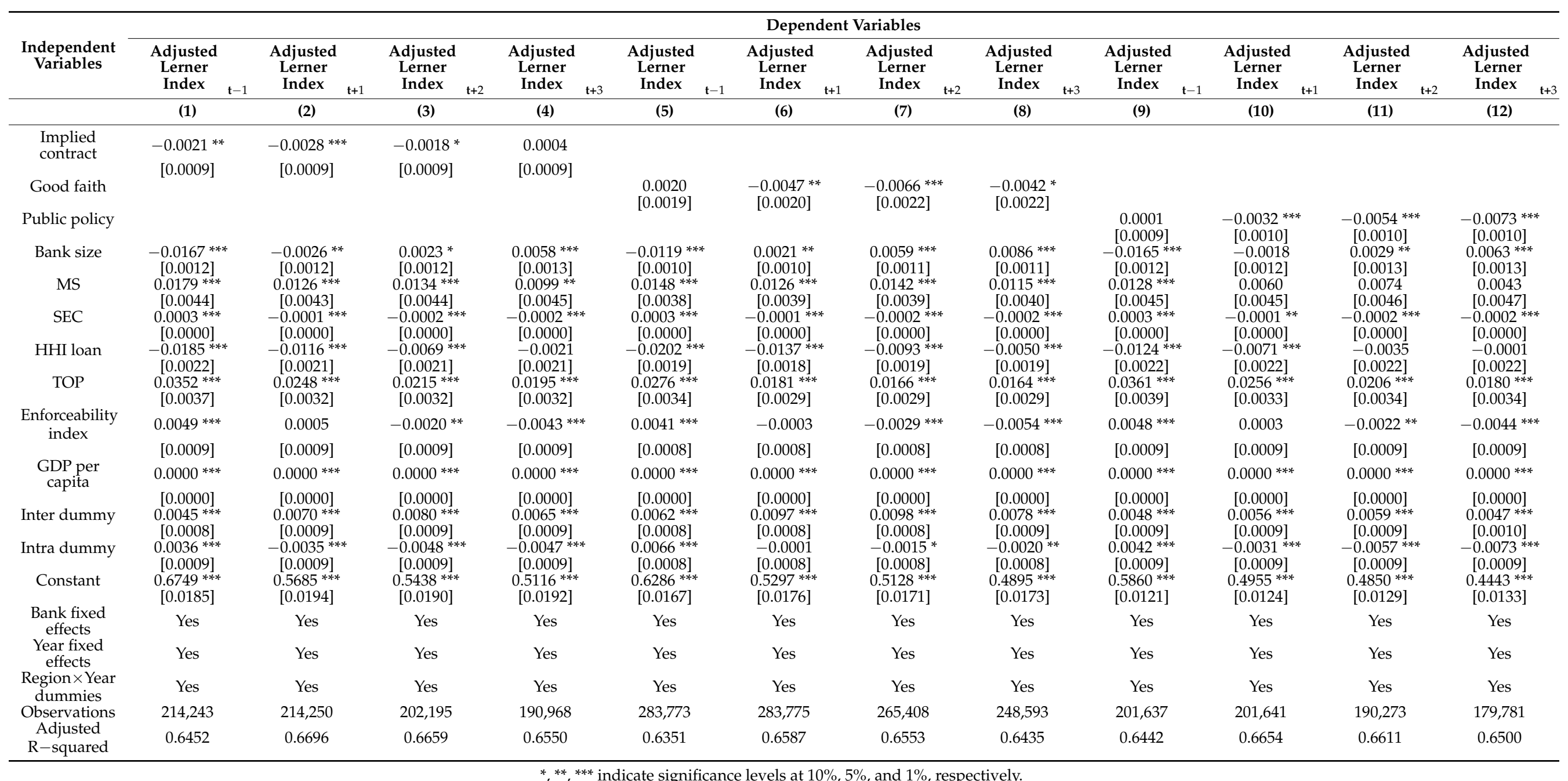


Table 4. Bank profit efficiency and cost efficiency: which one gets hurt?

\begin{tabular}{|c|c|c|c|c|c|c|}
\hline \multirow{3}{*}{$\begin{array}{c}\text { Independent } \\
\text { Variables }\end{array}$} & \multicolumn{6}{|c|}{ Dependent Variables } \\
\hline & \multicolumn{3}{|c|}{ Profit Efficiency } & \multicolumn{3}{|c|}{ Cost Efficiency } \\
\hline & (1) & (2) & (3) & (4) & (5) & (6) \\
\hline Implied contract & $\begin{array}{l}0.0006^{*} \\
{[0.0003]}\end{array}$ & & & $\begin{array}{c}-0.0018 * \\
{[0.0009]}\end{array}$ & & \\
\hline Good faith & & $\begin{array}{c}0.0008 \\
{[0.0007]}\end{array}$ & & & $\begin{array}{c}-0.0125^{* * *} \\
{[0.0021]}\end{array}$ & \\
\hline Public policy & & & $\begin{array}{l}-0.0005 \\
{[0.0004]}\end{array}$ & & & $\begin{array}{l}-0.0004 \\
{[0.0010]}\end{array}$ \\
\hline Bank size & $\begin{array}{c}-0.0070 * * * \\
{[0.0005]}\end{array}$ & $\begin{array}{c}-0.0081 * * * \\
{[0.0004]}\end{array}$ & $\begin{array}{c}-0.0077^{* * * *} \\
{[0.0004]}\end{array}$ & $\begin{array}{c}0.0165^{* * *} \\
{[0.0014]}\end{array}$ & $\begin{array}{c}0.0191 * * * \\
{[0.0011]}\end{array}$ & $\begin{array}{c}0.0170 * * * \\
{[0.0014]}\end{array}$ \\
\hline MS & $\begin{array}{c}0.0076^{* * *} \\
{[0.0017]}\end{array}$ & $\begin{array}{c}0.0100 * * * \\
{[0.0014]}\end{array}$ & $\begin{array}{c}0.0084^{* * *} \\
{[0.0017]}\end{array}$ & $\begin{array}{c}-0.0090 * \\
{[0.0048]}\end{array}$ & $\begin{array}{c}-0.0152^{* * *} \\
{[0.0042]}\end{array}$ & $\begin{array}{c}-0.0125^{* *} \\
{[0.0051]}\end{array}$ \\
\hline SEC & $\begin{array}{c}-0.0001 * * * \\
{[0.0000]}\end{array}$ & $\begin{array}{c}-0.0001 * * * \\
{[0.0000]}\end{array}$ & $\begin{array}{c}-0.0001^{* * *} \\
{[0.0000]}\end{array}$ & $\begin{array}{c}0.0005^{* * *} \\
{[0.0000]}\end{array}$ & $\begin{array}{c}0.0005^{* * *} \\
{[0.0000]}\end{array}$ & $\begin{array}{c}0.0005^{* * *} \\
{[0.0000]}\end{array}$ \\
\hline HHI loan & $\begin{array}{c}-0.0049^{* * *} \\
{[0.0008]}\end{array}$ & $\begin{array}{c}-0.0037 * * * \\
{[0.0007]}\end{array}$ & $\begin{array}{c}-0.0044^{* * * *} \\
{[0.0009]}\end{array}$ & $\begin{array}{c}0.0125^{* * *} \\
{[0.0021]}\end{array}$ & $\begin{array}{c}0.0110 * * * \\
{[0.0019]}\end{array}$ & $\begin{array}{c}0.0152 * * * \\
{[0.0023]}\end{array}$ \\
\hline TOP & $\begin{array}{c}0.0125^{* * *} \\
{[0.0012]}\end{array}$ & $\begin{array}{c}0.0123^{* * *} \\
{[0.0011]}\end{array}$ & $\begin{array}{c}0.0127^{* * *} \\
{[0.0013]}\end{array}$ & $\begin{array}{c}0.0120^{* * *} \\
{[0.0037]}\end{array}$ & $\begin{array}{c}0.0114^{* * *} \\
{[0.0032]}\end{array}$ & $\begin{array}{c}0.0128^{* * * *} \\
{[0.0040]}\end{array}$ \\
\hline Enforceability index & $\begin{array}{c}-0.0025^{* * *} \\
{[0.0003]}\end{array}$ & $\begin{array}{c}-0.0024^{* * *} \\
{[0.0003]}\end{array}$ & $\begin{array}{c}-0.0025^{* * * *} \\
{[0.0003]}\end{array}$ & $\begin{array}{c}0.0097^{* * * *} \\
{[0.0011]}\end{array}$ & $\begin{array}{c}0.0098^{* * *} \\
{[0.0010]}\end{array}$ & $\begin{array}{c}0.0104^{* * *} \\
{[0.0011]}\end{array}$ \\
\hline GDP per capita & $\begin{array}{l}-0.0000 \\
{[0.0000]}\end{array}$ & $\begin{array}{c}-0.0000 * * \\
{[0.0000]}\end{array}$ & $\begin{array}{l}-0.0000 \\
{[0.0000]}\end{array}$ & $\begin{array}{c}0.0000^{* * *} \\
{[0.0000]}\end{array}$ & $\begin{array}{c}0.0000^{* * *} \\
{[0.0000]}\end{array}$ & $\begin{array}{c}0.0000^{* * *} \\
{[0.0000]}\end{array}$ \\
\hline Inter dummy & $\begin{array}{c}0.0025 * * * \\
{[0.0003]}\end{array}$ & $\begin{array}{c}0.0024 * * * \\
{[0.0003]}\end{array}$ & $\begin{array}{c}0.0024 * * * \\
{[0.0003]}\end{array}$ & $\begin{array}{c}0.0065^{* * *} \\
{[0.0009]}\end{array}$ & $\begin{array}{c}0.0085^{* * *} \\
{[0.0008]}\end{array}$ & $\begin{array}{c}0.0076^{* * *} \\
{[0.0009]}\end{array}$ \\
\hline Intra dummy & $\begin{array}{c}0.0028^{* * * *} \\
{[0.0003]}\end{array}$ & $\begin{array}{c}0.0032 * * * \\
{[0.0003]}\end{array}$ & $\begin{array}{c}0.0029 * * * \\
{[0.0003]}\end{array}$ & $\begin{array}{c}-0.0018 \text { ** } \\
{[0.0008]}\end{array}$ & $\begin{array}{c}-0.0016^{* *} \\
{[0.0008]}\end{array}$ & $\begin{array}{c}0.0013 \\
{[0.0009]}\end{array}$ \\
\hline Constant & $\begin{array}{c}1.0330 * * * \\
{[0.0056]}\end{array}$ & $\begin{array}{c}1.0480^{* * * *} \\
{[0.0048]}\end{array}$ & $\begin{array}{l}1.0178 * * * \\
{[0.0045]}\end{array}$ & $\begin{array}{c}0.6249^{* * *} \\
{[0.0218]}\end{array}$ & $\begin{array}{c}0.6033^{* * *} \\
{[0.0192]}\end{array}$ & $\begin{array}{c}0.5904^{* * * *} \\
{[0.0138]}\end{array}$ \\
\hline Bank fixed effects & Yes & Yes & Yes & Yes & Yes & Yes \\
\hline Year fixed effects & Yes & Yes & Yes & Yes & Yes & Yes \\
\hline $\begin{array}{l}\text { Region } \times \text { Year } \\
\text { dummies }\end{array}$ & Yes & Yes & Yes & Yes & Yes & Yes \\
\hline Observations & 230,516 & 308,443 & 217,042 & 230,516 & 308,443 & 217,042 \\
\hline Adjusted R-squared & 0.4163 & 0.4075 & 0.4127 & 0.1095 & 0.1027 & 0.1087 \\
\hline
\end{tabular}

$*, * *, * * *$ indicate significance levels at $10 \%, 5 \%$, and $1 \%$, respectively.

To test the effects of WDLs on cost efficiency, which is the other component of banking power, relevant analyses are conducted and results are reported in columns 4-6 of Table 4 . Column 4 and 5 show that the adoption of implied contract and good faith significantly reduces cost efficiency, whereas the coefficient of public policy is insignificant. As proposed by Autor et al. [18], WDLs can offer protection against arbitrary or unfair firings, but may also impede employer performance by imposing litigation costs on employers. Therefore, the adoption of WDLs pressures managers to deviate from optimal cost frontier and decrease cost efficiency. Overall, based on our findings in Table 4, it is concluded that the negative relationship between the adoption of WDLs and banking power can be contributed to cost inefficiency but not profit efficiency.

\subsection{Wrongful Discharge Laws and Bank Costs}

As previously mentioned, increased employment protection makes termination of employees more difficult and increases firing costs. Analysis in this sub-section aims to provide empirical evidence to show how employment protection affects bank costs by investigating the effect of the adoption of WDLs on total operating costs, employment levels, and labor expenses. Because labor cost acts as an important input in measuring 
cost efficiency, it is reasonable to predict that cost inefficiency with the passage of WDLs stems from increased labor costs. In addition, the effects of WDLs on total operating costs are also tested, considering that labor protection laws create rigid labor costs, which also increase a firm's fixed costs and operating leverage [22]. Regressions are conducted to test the effects of WDLs on operating costs and labor costs respectively. The analysis follows existing study $[10,60]$ to mainly gauge three proxies for costs. Specifically, total operating costs is calculated as total operating costs divided by total assets, the price per labor is measured as wages scaled by the number of employees, and Number of employees/assets is calculated as the total number of employees scaled by total assets.

The results are reported in Table 5. Columns 1-3 report the effects of WDLs on total operating costs, columns 4-6 show the effects of WDLs on price per labor, and columns 7-9 report the effects of WDLs on Number of employees/assets. Columns 1-3 show that the adoption of public policy and good faith are both significantly and positively related to total operating costs, whereas the adoption of the implied contract doctrine does not affect operating costs significantly. Economically, an increase of one standard deviation of good faith and the public policy is associated with a $0.17 \%$ and $1.3 \%$ increase of total operating costs, respectively. Columns 7-9 show that the adoption of the implied-contract and good faith both significantly increase the scaled number of employees $(p<0.01)$. These findings are in line with the work of Bird and Knopf [60] that the reduced efficiency, arisen from discharge protection, may cause demand for labor to drive inward and therefore increase labor employment. In columns 4-5, although the coefficient estimate of public policy on price per labor is negative, the magnitude is small and does not affect the overall conclusion. The effect of good faith on labor costs is both economically and statistically significant $(p<0.01)$, and the adoption of good faith significantly increases the price per labor by $1.62 \%$. These results confirm the predictions and provide consistent empirical evidence with previous studies that wrongful-discharge laws impose costs on employers $[28,76]$, such as revising employment handbooks, implementing bureaucratic discharge procedures, increasing documentation requirements, and retaining unproductive employees. In conclusion, the findings provide consistent results with the previous findings that WDLs are negatively related with cost efficiency, and such negative relation is mainly driven by increases of operating costs and labor costs.

\subsection{Does the Adoption of WDLs Encourage Bank Risky Performance?}

In this sub-section, analysis is extended to examine how and to what extent labor protection laws affect bank risk. Various alternative measures are used to proxy for bank risk. The first risk measure is denoted as Z-score, which is widely adopted in empirical research as an indicator of financial stability $[72,77,78]$. Specifically, $Z-$ score $=(R O A+E / A) / \sigma(R O A)$, where $R O A, E / A$, and $\sigma(R O A)$ are the mean return on assets, the mean equity-to-asset ratio, and the standard deviation of $R O A$, respectively. Z-score is calculated based on a three-year window from year $t-2$ to year $t$. The $Z$-score has an inverse relationship with bank insolvency risk and captures the likelihood that a bank will go out of business due to insufficient capital to compensate for a decrease in asset value [78]. As in Laeven and Levine [72], the natural logarithm of the Z-score is included in the test to normalize the distribution. In addition, like existing literature [79-82], this study also includes measures of the standard deviation of $R O A$ and standard deviation of $R O E$ over a four-year window for each bank in each year as another two measures to proxy for bank risk-taking. Std. dev of $R O A$ is denoted as the standard deviation of return on assets on a yearly basis using quarterly data, and Std. dev of $R O E$ is measured as the standard deviation of return on equity in the similar way. 
Table 5. The effects of wrongful discharge laws on bank costs.

\begin{tabular}{|c|c|c|c|c|c|c|c|c|c|}
\hline \multirow{3}{*}{$\begin{array}{c}\text { Independent } \\
\text { Variables }\end{array}$} & \multicolumn{9}{|c|}{ Dependent Variables } \\
\hline & \multicolumn{3}{|c|}{ Total Operating Costs } & \multicolumn{3}{|c|}{ Price per Labor } & \multicolumn{3}{|c|}{ Number of Employees/Assets } \\
\hline & (1) & (2) & (3) & (4) & (5) & (6) & (7) & (8) & (9) \\
\hline Implied & -0.0000 & & & -0.0004 & & & $0.0117^{* * *}$ & & \\
\hline Good faith & [0.0002] & $\begin{array}{c}0.0017^{* * *} \\
{[0.0004]}\end{array}$ & & [0.0019] & $\begin{array}{c}0.0162^{* * *} \\
{[0.0041]}\end{array}$ & & {$[0.0025]$} & $\begin{array}{c}0.0382 * * * \\
{[0.0053]}\end{array}$ & \\
\hline Public policy & & & $\begin{array}{l}0.0003 * * \\
{[0.0002]}\end{array}$ & & & $\begin{array}{c}-0.0054^{* * *} \\
{[0.0020]}\end{array}$ & & & $\begin{array}{l}-0.0038 \\
{[0.0025]}\end{array}$ \\
\hline Bank size & $\begin{array}{c}0.0000 \\
{[0.0002]}\end{array}$ & $\begin{array}{l}0.0003 * \\
{[0.0002]}\end{array}$ & $\begin{array}{l}-0.0000 \\
{[0.0002]}\end{array}$ & $\begin{array}{c}-0.0331 * * * \\
{[0.0024]}\end{array}$ & $\begin{array}{c}-0.0371 * * * \\
{[0.0020]}\end{array}$ & $\begin{array}{c}-0.0294^{* * *} \\
{[0.0024]}\end{array}$ & $\begin{array}{c}-0.1578 * * * \\
{[0.0033]}\end{array}$ & $\begin{array}{c}-0.1552 * * * \\
{[0.0026]}\end{array}$ & $\begin{array}{c}-0.1650^{* * *} \\
{[0.0033]}\end{array}$ \\
\hline MS & $\begin{array}{c}-0.0020^{* * *} \\
{[0.0007]}\end{array}$ & $\begin{array}{c}-0.0023^{* * *} \\
{[0.0007]}\end{array}$ & $-0.0014{ }^{*}$ & $\begin{array}{c}0.0522 * * * \\
{[0.0079]}\end{array}$ & $\begin{array}{c}0.0517^{* * *} \\
{[0.0068]}\end{array}$ & $\begin{array}{c}0.0398^{* * * *} \\
{[0.0082]}\end{array}$ & $\begin{array}{c}0.1488^{* * *} \\
{[0.0126]}\end{array}$ & $\begin{array}{c}0.1629 * * * \\
{[0.0106]}\end{array}$ & $\begin{array}{c}0.1753^{* * *} \\
{[0.0131]}\end{array}$ \\
\hline SEC & $\begin{array}{c}-0.0001^{* * *} \\
{[0.0000]}\end{array}$ & $\begin{array}{c}-0.0001 * * * \\
{[0.0000]}\end{array}$ & $\begin{array}{c}-0.0002^{* * *} \\
{[0.0000]}\end{array}$ & $\begin{array}{c}-0.0003 * * * \\
{[0.0001]}\end{array}$ & $-0.0003^{* * *}$ & $\begin{array}{c}-0.0003^{* * *} \\
{[0.0001]}\end{array}$ & $-0.0012 * * *$ & $-0.0012^{* * *}$ & $\begin{array}{c}-0.0012^{* * *} \\
{[0.0001]}\end{array}$ \\
\hline HHI loan & $\begin{array}{l}0.0014^{* * *} \\
{[0.0003]}\end{array}$ & $0.0013^{* * *}$ & $0.0006^{*}$ & $-0.0572^{* * *}$ & $-0.0663^{* * *}$ & $\begin{array}{c}-0.0512^{* * *} \\
{[0.0049]}\end{array}$ & $\begin{array}{l}0.0101 * \\
{[0.0057]}\end{array}$ & $0.0087^{*}$ & 0.0023 \\
\hline TOP & $\begin{array}{l}-0.0006 \\
{[0.0005]}\end{array}$ & $\begin{array}{l}-0.0007 \\
{[0.0005]}\end{array}$ & $\begin{array}{l}-0.0011{ }^{*} \\
{[0.0006]}\end{array}$ & $\begin{array}{c}0.0288^{* * * *} \\
{[0.0054]}\end{array}$ & $\begin{array}{c}0.0269 * * * \\
{[0.0047]}\end{array}$ & $\begin{array}{c}0.0327^{* * * *} \\
{[0.0056]}\end{array}$ & $\begin{array}{l}0.0207 * * \\
{[0.0098]}\end{array}$ & $\begin{array}{l}{\left[0.02077^{* *}\right.} \\
{[0.0082]}\end{array}$ & $\begin{array}{c}0.0275^{* * * *} \\
{[0.0104]}\end{array}$ \\
\hline $\begin{array}{c}\text { Enforceability } \\
\text { index }\end{array}$ & -0.0001 & -0.0001 & -0.0001 & 0.0006 & -0.0005 & -0.0019 & $-0.0244^{* * *}$ & $-0.0237^{* * *}$ & $-0.0253^{* * *}$ \\
\hline & {$[0.0001]$} & {$[0.0001]$} & [0.0001] & [0.0017] & {$[0.0016]$} & {$[0.0018]$} & [0.0023] & [0.0021] & [0.0023] \\
\hline GDP per capita & $-0.0000^{* * *}$ & $\begin{array}{l}-0.0000^{* * *} \\
{[0.0000]}\end{array}$ & $\begin{array}{c}-0.0000^{* * *} \\
{[0.0000]}\end{array}$ & $\begin{array}{c}0.0000 * * * \\
{[0.0000]}\end{array}$ & $\begin{array}{l}0.0000^{* * * *} \\
{[0.0000]}\end{array}$ & $\begin{array}{l}0.0000^{* * *} \\
{[0.0000]}\end{array}$ & $\begin{array}{c}-0.0000^{* * *} \\
{[0.0000]}\end{array}$ & $-0.0000^{* * *}$ & $\begin{array}{l}-0.0000^{* * *} \\
{[0.0000]}\end{array}$ \\
\hline Inter dummy & $-0.0018^{* * *}$ & $\begin{array}{c}-0.0022 * * * \\
{[0.0001]}\end{array}$ & $\begin{array}{c}-0.0019^{* * *} \\
{[0.0002]}\end{array}$ & $\begin{array}{c}-0.0117 * * * \\
{[0.0017]}\end{array}$ & $-0.0082^{* * *}$ & $\begin{array}{c}-0.0130^{* * *} \\
{[0.0018]}\end{array}$ & $\begin{array}{c}0.0032 \\
{[0.0020]}\end{array}$ & {$\left[0.0042^{* *}\right.$} & $\begin{array}{c}0.0055^{* * *} \\
{[0.0021]}\end{array}$ \\
\hline Intra dummy & $-0.0003^{* *}$ & $\begin{array}{c}-0.0007^{* * *} \\
{[0.0001]}\end{array}$ & $\begin{array}{c}-0.0009^{* * *} \\
{[0.0001]}\end{array}$ & $\begin{array}{c}-0.0111 * * * \\
{[0.0017]}\end{array}$ & $-0.0081^{* * *}$ & $\begin{array}{c}-0.0086^{* * *} \\
{[0.0018]}\end{array}$ & $\begin{array}{c}0.0114^{* * *} \\
{[0.0023]}\end{array}$ & $\begin{array}{c}0.0122 * * * \\
{[0.0021]}\end{array}$ & $\begin{array}{c}0.0092^{* * * *} \\
{[0.0024]}\end{array}$ \\
\hline Constant & $\begin{array}{c}0.0529^{* * *} \\
{[0.0025]}\end{array}$ & $\begin{array}{c}0.0495^{* * *} \\
{[0.0021]}\end{array}$ & $\begin{array}{c}0.0616^{* * *} \\
{[0.0019]}\end{array}$ & $\begin{array}{c}0.1969^{* * *} \\
{[0.0294]}\end{array}$ & $\begin{array}{c}0.2301 * * * \\
{[0.0252]}\end{array}$ & $\begin{array}{c}0.1180^{* * *} \\
{[0.0253]}\end{array}$ & $\begin{array}{c}2.8973^{* * *} \\
{[0.0517]}\end{array}$ & $\begin{array}{c}2.8366^{* * *} \\
{[0.0459]}\end{array}$ & $\begin{array}{c}2.8834^{* * *} \\
{[0.0328]}\end{array}$ \\
\hline $\begin{array}{l}\text { Bank fixed } \\
\text { effects }\end{array}$ & Yes & Yes & Yes & Yes & Yes & Yes & Yes & Yes & Yes \\
\hline $\begin{array}{c}\text { Year fixed } \\
\text { effects }\end{array}$ & Yes & Yes & Yes & Yes & Yes & Yes & Yes & Yes & Yes \\
\hline $\begin{array}{l}\text { Region } \times \text { Year } \\
\text { dummies }\end{array}$ & Yes & Yes & Yes & Yes & Yes & Yes & Yes & Yes & Yes \\
\hline Observations & 230,516 & 308,443 & 217,042 & 230,516 & 308,443 & 217,042 & 230,516 & 308,443 & 217,042 \\
\hline $\begin{array}{c}\text { Adjusted } \\
\mathrm{R} \text {-squared }\end{array}$ & 0.7381 & 0.7161 & 0.7288 & 0.9094 & 0.9016 & 0.9076 & 0.7694 & 0.7574 & 0.7733 \\
\hline
\end{tabular}

$*, * *, * *$ indicate significance levels at $10 \%, 5 \%$, and $1 \%$, respectively.

The results are reported in Table 6. Columns 1-3 focus on implied contract, whereas columns 4-6 focus on good faith, and columns 7-9 focus on public policy. Consistent negative and significant coefficients of all three WDLs are observed when the dependent variable is Z-score $(p<0.01)$. This finding reveals that the adoption of WDLs leads to an increase of the overall risk-taking level for each bank. In addition, positive and significant coefficients are also found when dependent variables are Std. dev of ROA and Std. dev of $R O E$ separately $(p<0.01)$. Overall, consistent results are found for all those three doctrines and reach to the conclusion that the adoption of WDLs positively affects bank risk-taking. These findings also confirm with the moral hazard hypothesis that inefficient banks are more vulnerable to risk-taking than efficient banks [5]. 
Table 6. Does the adoption of wrongful discharge laws affect bank risky performance?

\begin{tabular}{|c|c|c|c|c|c|c|c|c|c|}
\hline \multirow{3}{*}{$\begin{array}{c}\text { Independent } \\
\text { Variables }\end{array}$} & \multicolumn{9}{|c|}{ Dependent Variables } \\
\hline & \multicolumn{3}{|c|}{$\mathrm{Z}$-score } & \multicolumn{3}{|c|}{ Std. dev of $R O A$} & \multicolumn{3}{|c|}{ Std. dev of $R O E$} \\
\hline & (1) & (2) & (3) & (4) & (5) & (6) & (7) & (8) & (9) \\
\hline $\begin{array}{l}\text { Implied } \\
\text { contract }\end{array}$ & $-0.0573^{* * *}$ & & & $0.0002 * * *$ & & & $0.0049^{* * *}$ & & \\
\hline Good faith & [0.0116] & $\begin{array}{c}-0.1670^{* * *} \\
{[0.0281]}\end{array}$ & & {$[0.0001]$} & $\begin{array}{c}0.0011^{* * *} \\
{[0.0002]}\end{array}$ & & {$[0.0011]$} & $\begin{array}{c}0.0179^{* * *} \\
{[0.0033]}\end{array}$ & \\
\hline Public policy & & & $\begin{array}{c}-0.0418^{* * *} \\
{[0.0126]}\end{array}$ & & & $\begin{array}{l}0.0001 * \\
{[0.0001]}\end{array}$ & & & $\begin{array}{c}0.0051^{* * *} \\
{[0.0012]}\end{array}$ \\
\hline Bank size & $\begin{array}{c}0.1282^{* * *} \\
{[0.0144]}\end{array}$ & $\begin{array}{c}0.1642^{* * *} \\
{[0.0123]}\end{array}$ & $\begin{array}{c}0.1311^{* * * *} \\
{[0.0145]}\end{array}$ & $\begin{array}{c}-0.0015^{* * *} \\
{[0.0001]}\end{array}$ & $\begin{array}{c}-0.0017^{* * *} \\
{[0.0001]}\end{array}$ & $-0.0016^{* * * *}$ & $\begin{array}{c}-0.0219^{* * *} \\
{[0.0014]}\end{array}$ & $\begin{array}{c}-0.0237^{* * *} \\
{[0.0012]}\end{array}$ & $\begin{array}{c}-0.0228^{* * * *} \\
{[0.0014]}\end{array}$ \\
\hline MS & $\begin{array}{l}-0.0294 \\
{[0.0503]}\end{array}$ & $\begin{array}{l}-0.0245 \\
{[0.0444]}\end{array}$ & $\begin{array}{l}-0.0360 \\
{[0.0514]}\end{array}$ & $\begin{array}{c}0.0012^{* * * *} \\
{[0.0003]}\end{array}$ & $\begin{array}{c}0.0013^{* * * *} \\
{[0.0002]}\end{array}$ & $\begin{array}{c}0.0013^{* * *} \\
{[0.0003]}\end{array}$ & $\begin{array}{c}0.0144^{* * * *} \\
{[0.0043]}\end{array}$ & $\begin{array}{c}0.0164^{* * *} \\
{[0.0038]}\end{array}$ & $\begin{array}{c}0.0162^{* * * *} \\
{[0.0045]}\end{array}$ \\
\hline SEC & $0.0045^{* * * *}$ & $0.0050^{* * * *}$ & $0.0048^{* * * *}$ & $-0.0000^{* * * *}$ & $-0.0000^{* * * *}$ & $-0.0000^{* * *}$ & $-0.0003^{* * * *}$ & $-0.0003^{* * * *}$ & $-0.0003^{* * * *}$ \\
\hline HHI loan & $\begin{array}{c}0.1749^{* * *} \\
{[0.0263]}\end{array}$ & $\begin{array}{c}0.1645^{* * * *} \\
{[0.0233]}\end{array}$ & $\begin{array}{c}0.2042^{* * * *} \\
{[0.0276]}\end{array}$ & $\begin{array}{c}-0.0006^{* * *} \\
{[0.0001]}\end{array}$ & $\begin{array}{c}-0.0006^{* * *} \\
{[0.0001]}\end{array}$ & $\begin{array}{c}-0.0008^{* * * *} \\
{[0.0001]}\end{array}$ & $\begin{array}{c}-0.0122^{* * * *} \\
{[0.0024]}\end{array}$ & $\begin{array}{c}-0.0111^{* * * *} \\
{[0.0021]}\end{array}$ & $\begin{array}{c}-0.0157^{* * * *} \\
{[0.0025]}\end{array}$ \\
\hline TOP & $\begin{array}{c}-0.2275^{* * * *} \\
{[0.0432]}\end{array}$ & $\begin{array}{c}-0.2098^{* * *} \\
{[0.0383]}\end{array}$ & $\begin{array}{c}-0.1847^{* * *} \\
{[0.0440]}\end{array}$ & $\begin{array}{c}0.0017^{* * * *} \\
{[0.0002]}\end{array}$ & $\begin{array}{c}0.0017^{* * * *} \\
{[0.0002]}\end{array}$ & $\begin{array}{c}0.0016^{* * *} \\
{[0.0002]}\end{array}$ & $\begin{array}{c}0.0222^{* * * *} \\
{[0.0034]}\end{array}$ & $\begin{array}{c}0.0221 * * * \\
{[0.0030]}\end{array}$ & $\begin{array}{c}0.0208^{* * * *} \\
{[0.0036]}\end{array}$ \\
\hline $\begin{array}{l}\text { Enforceability } \\
\text { index }\end{array}$ & $-0.0476^{* * *}$ & $-0.0471^{* * *}$ & $-0.0343^{* * *}$ & $0.0003^{* * *}$ & $0.0003^{* * *}$ & $0.0002 * * *$ & $0.0063^{* * *}$ & $0.0062^{* * *}$ & $0.0049^{* * *}$ \\
\hline & [0.0103] & {$[0.0098]$} & [0.0103] & {$[0.0001]$} & {$[0.0001]$} & {$[0.0001]$} & [0.0010] & {$[0.0010]$} & {$[0.0010]$} \\
\hline $\begin{array}{l}\text { GDP per } \\
\text { capita }\end{array}$ & $0.0000^{* * *}$ & $0.0000^{* * *}$ & $0.0000^{* * *}$ & $-0.0000^{* * *}$ & $-0.0000^{* * *}$ & $-0.0000 * * *$ & $-0.0000 * * *$ & $-0.0000^{* * *}$ & $-0.0000^{* * *}$ \\
\hline & {$[0.0000]$} & {$[0.0000]$} & {$[0.0000]$} & {$[0.0000]$} & {$[0.0000]$} & {$[0.0000]$} & {$[0.0000]$} & {$[0.0000]$} & {$[0.0000]$} \\
\hline Inter dummy & $\begin{array}{c}0.1379^{* * *} \\
{[0.0135]}\end{array}$ & $\begin{array}{c}0.1774^{* * * *} \\
{[0.0127]}\end{array}$ & $\begin{array}{c}0.1421^{* * * *} \\
{[0.0141]}\end{array}$ & $\begin{array}{c}-0.0007^{* * *} \\
{[0.0001]}\end{array}$ & $\begin{array}{c}-0.0010^{* * *} \\
{[0.0001]}\end{array}$ & $\begin{array}{c}-0.0007^{* * * *} \\
{[0.0001]}\end{array}$ & $\begin{array}{c}-0.0102^{* * *} \\
{[0.0015]}\end{array}$ & $\begin{array}{c}-0.0144^{* * * *} \\
{[0.0014]}\end{array}$ & $\begin{array}{l}-0.0109^{* * * *} \\
{[0.0016]}\end{array}$ \\
\hline Intra dummy & $-0.0478^{* * * *}$ & $-0.0212^{* *}$ & $-0.0331 * * * *$ & $0.0002^{* * * *}$ & -0.0000 & 0.0001 & $0.0038^{* * *}$ & 0.0006 & $\begin{array}{l}0.0028^{* *} \\
{[0.0011]}\end{array}$ \\
\hline Constant & $\begin{array}{c}2.9397^{* * *} \\
{[0.2066]}\end{array}$ & $\begin{array}{c}2.7003^{* * * *} \\
{[0.1804]}\end{array}$ & $\begin{array}{c}2.2121^{* * *} \\
{[0.1485]}\end{array}$ & $\begin{array}{c}0.0154^{* * *} \\
{[0.0013]}\end{array}$ & $\begin{array}{c}0.0170^{* * *} \\
{[0.0011]}\end{array}$ & $\begin{array}{c}0.0182^{* * * *} \\
{[0.0008]}\end{array}$ & $\begin{array}{c}0.2110^{* * * *} \\
{[0.0288]}\end{array}$ & $\begin{array}{c}0.2154^{* * *} \\
{[0.0256]}\end{array}$ & $\begin{array}{c}0.2551^{* * * *} \\
{[0.0141]}\end{array}$ \\
\hline $\begin{array}{l}\text { Bank fixed } \\
\text { effects }\end{array}$ & Yes & Yes & Yes & Yes & Yes & Yes & Yes & Yes & Yes \\
\hline $\begin{array}{l}\text { Year fixed } \\
\text { effects }\end{array}$ & Yes & Yes & Yes & Yes & Yes & Yes & Yes & Yes & Yes \\
\hline $\begin{array}{l}\text { Region } \times \text { Year } \\
\text { dummies }\end{array}$ & Yes & Yes & Yes & Yes & Yes & Yes & Yes & Yes & Yes \\
\hline Observations & 208,428 & 273,783 & 196,440 & 208,428 & 273,783 & 196,440 & 208,428 & 273,783 & 196,440 \\
\hline $\begin{array}{c}\text { Adjusted } \\
\mathrm{R}-\text { squared }\end{array}$ & 0.1281 & 0.1246 & 0.1364 & 0.0911 & 0.0924 & 0.0985 & 0.0833 & 0.0823 & 0.0893 \\
\hline
\end{tabular}

$*, * * * * *$ indicate significance levels at $10 \%, 5 \%$, and $1 \%$, respectively.

\section{Discussion}

This article attempts to identify the effects of employment protection laws on banking power by exploiting the quasi-natural experiment created by the adoption of WDLs by U.S. state courts. Banking power and bank efficiencies are gauged at individual bank level by using a stochastic frontier analysis [10], and banking power is measured as an adjusted Lerner index. A DID approach is employed within a five-year window surrounding the year when states adopt wrongful discharge laws. The main findings show a causal effect of state-level employment protection laws on firm-specific banking power. The study further explores a possible mechanism through which the WDLs affect banking power. These empirical results reveal that banking power decreases with the adoption of wrongful discharge laws, and such reduction effect is mainly due to the reduction of bank cost efficiency but not profit efficiency. Moreover, this study indicates that the adoption of wrongful discharge laws increases bank operating costs and labor expenses, and provides consistent evidence with previous studies that employment protection laws impose costs on employers $[28,60,76]$. The effects of wrongful discharge laws on bank risky performance are also tested, and the results indicate that the adoption of wrongful discharge laws increases bank risks.

This research reveals an important potential negative economic consequence to bank market power and bank efficiencies after the adoption of WDLs, and such reduction effects may factor into investment decisions for constrained banks that are located in states with the adoption of WDLs. These results align with related research concluding that wrongful-discharge laws reduce banking power and bank cost efficiency, impose costs 
upon employers, and increase bank risks. Furthermore, this work contributes to the existing literature by providing new insights into how U.S. employment protection laws can also shape bank market power and bank efficiencies.

\section{Conclusions}

This investigation provides empirical evidence to show that WDLs, as a quasi-natural shock to employment protection, significantly reduce banking power. Although this study alone cannot suggest whether the adoption of WDLs is beneficial for a court or legislature, this paper still has important implications for bank managers. Moreover, this research can raise important questions for future research. This investigation could help understand the mechanism through which the labor protection law affects bank behavior. For example, due to deregulation and technological development, the US banking industry has experienced a tremendous level of merger and acquisitions (M\&As). It is worthwhile to investigate how the labor market frictions can affect bank merger and acquisition activities. In addition, according to Deng, et al. [83], M\&A activities are associated with different dimensions of diversification, for example, geographic expansion, and diversification of assets, activities, and markets. Another important area for future research to better link labor market and bank diversification.

Author Contributions: Conceptualization, X.Z. and D.Y.; formal analysis, X.Z.; investigation, X.Z.; methodology, X.Z.; software, X.Z.; supervision, D.Y.; writing-original draft preparation, X.Z.; writing-review and editing, X.Z. and D.Y. All authors have read and agreed to the published version of the manuscript.

Funding: This research received no external funding.

Institutional Review Board Statement: Not applicable.

Informed Consent Statement: Not applicable.

Data Availability Statement: Not applicable.

Conflicts of Interest: The authors declare no conflict of interest.

\section{Appendix A. State-Level Wrongful Discharge Laws}

Following Autor, et al. [18], we provide this table to show the year and month when each state passed three Wrongful Discharge Laws (good faith, implied contract, and public policy exceptions to the traditional employment-at-will rule).

Table A1. State-Level Wrongful Discharge Laws

\begin{tabular}{|c|c|c|c|c|c|c|c|}
\hline \multirow[t]{2}{*}{ State } & \multicolumn{2}{|c|}{$\begin{array}{l}\text { Implied Contract } \\
\text { Exception Passed }\end{array}$} & \multicolumn{2}{|c|}{$\begin{array}{c}\text { Public Policy } \\
\text { Exception Passed }\end{array}$} & \multicolumn{2}{|c|}{$\begin{array}{c}\text { Good Faith } \\
\text { Exception Passed }\end{array}$} & \multirow[t]{2}{*}{ Note } \\
\hline & Year & Month & Year & Month & Year & Month & \\
\hline Alabama & 1987 & 7 & & & & & \multirow{8}{*}{$\begin{array}{l}\text { Implied Contract Exception } \\
\text { reversed } 4 / 1984\end{array}$} \\
\hline Alaska & 1983 & 5 & 1986 & 2 & 1983 & 5 & \\
\hline Arizona & 1983 & 6 & 1985 & 6 & 1985 & 6 & \\
\hline Arkansas & 1984 & 6 & 1980 & 3 & & & \\
\hline California & 1972 & 3 & 1970 & 1 & 1980 & 10 & \\
\hline Colorado & 1983 & 10 & 1985 & 9 & & & \\
\hline Connecticut & 1985 & 10 & 1980 & 1 & 1980 & 6 & \\
\hline $\begin{array}{l}\text { Delaware } \\
\text { Florida } \\
\text { Georoia }\end{array}$ & & & 1992 & 3 & 1992 & 4 & \\
\hline
\end{tabular}


Table A1. Cont.

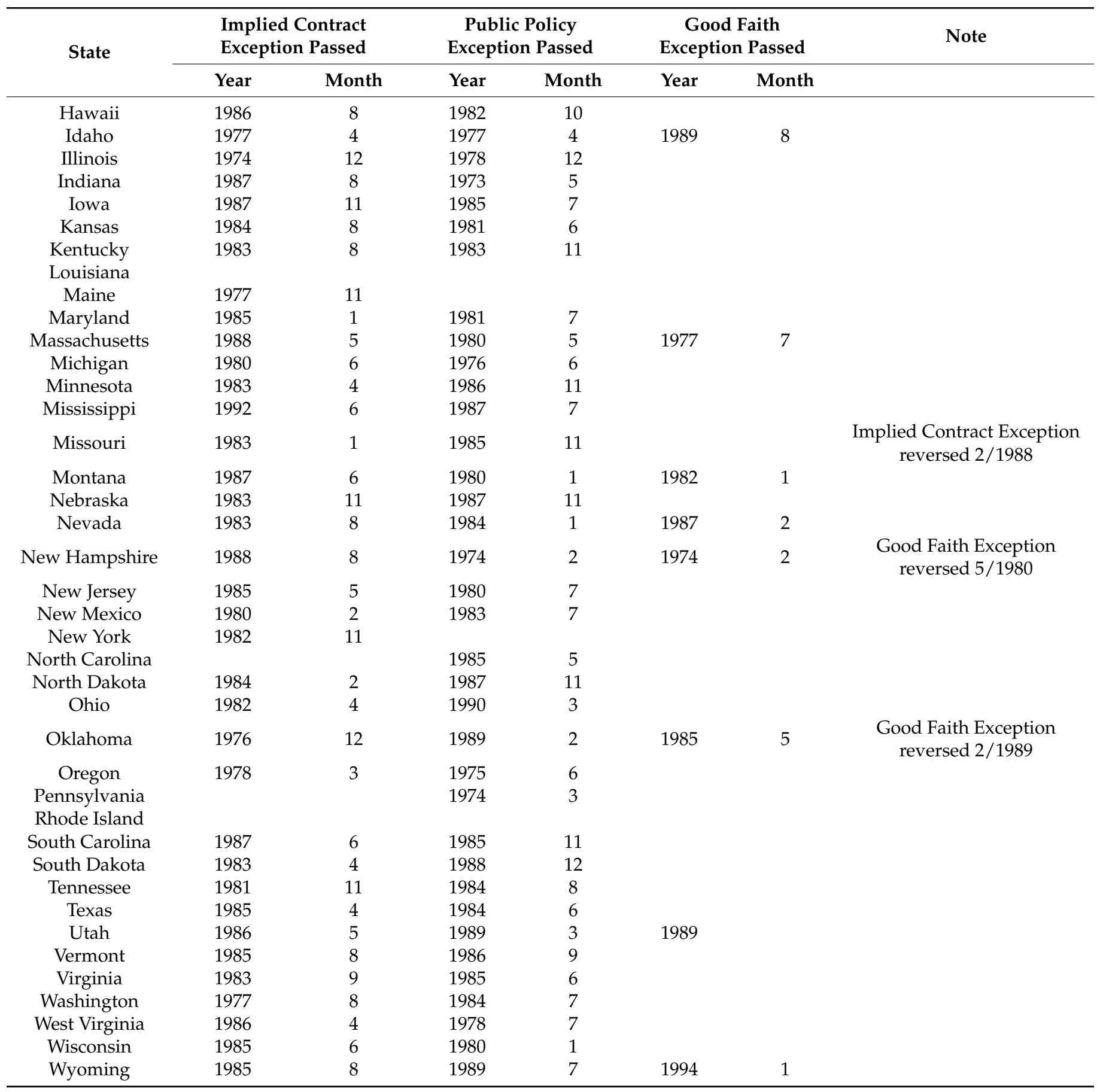

\section{References}

1. Lerner, A.P. The concept of monopoly and the measurement of monopoly power. Rev. Econ. Stud. 1934, 1, 157-175. [CrossRef]

2. Berger, A.N.; Hannan, T.H. The efficiency cost of market power in the banking industry: A test of the "quiet life" and related hypotheses. Rev. Econ. Statist. 1998, 80, 454-465. [CrossRef]

3. Maudos, J.; de Guevara, J.F. The cost of market power in banking: Social welfare loss vs. cost inefficiency. J. Bank. Financ. 2007, 31, 2103-2125. [CrossRef]

4. Hicks, J.R. Annual survey of economic theory: The theory of monopoly. Econom. J. Econom. Soc. 1935. [CrossRef]

5. Kwan, S.; Eisenbeis, R.A. Bank risk, capitalization, and operating efficiency. J. Financ. Serv. Res. 1997, 12, 117-131. [CrossRef]

6. Bernanke, B.S. Non-Monetary Effects of the Financial Crisis in the Propagation of the Great Depression; National Bureau of Economic Research: Cambridge, MA, USA, 1983. 
7. Calomiris, C.W.; Mason, J.R. Consequences of bank distress during the Great Depression. Am. Econ. Rev. 2003, 93, 937-947. [CrossRef]

8. Keeley, M.C. Deposit insurance, risk, and market power in banking. Am. Econ. Rev. 1990, 80, 1183-1200.

9. Berger, A.N.; Hunter, W.C.; Timme, S.G. The efficiency of financial institutions: A review and preview of research past, present and future. J. Bank. Financ. 1993, 17, 221-249. [CrossRef]

10. Koetter, M.; Kolari, J.W.; Spierdijk, L. Enjoying the quiet life under deregulation? Evidence from adjusted Lerner indices for US banks. Rev. Econ. Statist. 2012, 94, 462-480. [CrossRef]

11. Angelini, P.; Cetorelli, N. The effects of regulatory reform on competition in the banking industry. J. Money Credit. Bank. 2003, 35, 663-684. [CrossRef]

12. Carbó, S.; Humphrey, D.; Maudos, J.; Molyneux, P. Cross-country comparisons of competition and pricing power in European banking. J. Int. Money Financ. 2009, 28, 115-134. [CrossRef]

13. Fairhurst, D.D.; Liu, Y.; Ni, X. Employment protection and tax aggressiveness: Evidence from wrongful discharge laws. J. Bank. Financ. 2020, 119, 105907. [CrossRef]

14. Bai, J.; Fairhurst, D.; Serfling, M. Employment protection, investment, and firm growth. Rev. Financ. Stud. 2020, 33, 644-688. [CrossRef]

15. Simintzi, E.; Vig, V.; Volpin, P. Labor protection and leverage. Rev. Financ. Stud. 2015, 28, 561-591. [CrossRef]

16. Autor, D.H.; Donohue, J.J.; Schwab, S.J. The employment consequences of wrongful-discharge laws: Large, small, or none at all? Am. Econ. Rev. 2004, 94, 440-446. [CrossRef]

17. Morriss, A.P. Exploding myths: An empirical and economic reassessment of the rise of employment at-will. Mo. L. Rev. 1994, 59, 679-773.

18. Autor, D.H.; Donohue, J.J., III; Schwab, S.J. The costs of wrongful-discharge laws. Rev. Econ. Stat. 2006, 88, 211-231. [CrossRef]

19. Autor, D.H.; Kerr, W.R.; Kugler, A.D. Does employment protection reduce productivity? Evidence from US states. Econ. J. 2007, 117, F189-F217. [CrossRef]

20. Acharya, V.V.; Baghai, R.P.; Subramanian, K.V. Labor laws and innovation. J. Law Econ. 2013, 56, 997-1037. [CrossRef]

21. MacLeod, W.B.; Nakavachara, V. Can wrongful discharge law enhance employment? Econ. J. 2007, 117, F218-F278. [CrossRef]

22. Serfling, M. Firing costs and capital structure decisions. J. Financ. 2016, 71, 2239-2286. [CrossRef]

23. Karpuz, A.; Kim, K.; Ozkan, N. Employment protection laws and corporate cash holdings. J. Bank. Financ. 2020, $111,105705$. [CrossRef]

24. Qiu, Y. Labor adjustment costs and risk management. J. Financ. Quant. Anal. 2019, 54, 1447-1468. [CrossRef]

25. Dang, V.A.; De Cesari, A.; Phan, H.V. Employment Protection and Share Repurchases: Evidence from Wrongful Discharge Laws. Available online: https:/ /ssrn.com/abstract=3188011 (accessed on 1 September 2020).

26. Gao, H.; Huang, J. Employee Firing Costs and Accounting Conservatism: Evidence from Wrongful Discharge Laws. Available online: https: / / ssrn.com/abstract=3276474 (accessed on 20 November 2019).

27. Rhoades, S.A.; Rutz, R.D. The impact of bank holding companies on local market rivalry and performance. J. Econ. Bus. 1982, 34, 355-365. [CrossRef]

28. Autor, D.H. Outsourcing at will: The contribution of unjust dismissal doctrine to the growth of employment outsourcing. J. Lab. Econ. 2003, 21. [CrossRef]

29. Kim, Y.; Li, S.; Park, H. Wrongful discharge laws and asymmetric cost behavior. J. Law Financ. Account. 2020, 5, 65-105. [CrossRef]

30. Becker, G.S. Investment in human capital: A theoretical analysis. J. Polit. Econ. 1962, 70, 9-49. [CrossRef]

31. Hashimoto, M. Firm-specific human capital as a shared investment. Am. Econ. Rev. 1981, 71, 475-482. [CrossRef]

32. Schultz, T.W. Investment in human capital. Am. Econ. Rev. 1961, 51, 1-17.

33. Berger, A.N.; Humphrey, D.B. Efficiency of financial institutions: International survey and directions for future research. Eur. J. Oper. Res. 1997, 98, 175-212. [CrossRef]

34. Buch, C.M.; Koch, C.T.; Koetter, M. Do banks benefit from internationalization? Revisiting the market power-risk nexus. Rev. Financ. 2013, 17, 1401-1435. [CrossRef]

35. Hellmann, T.F.; Murdock, K.C.; Stiglitz, J.E. Liberalization, moral hazard in banking, and prudential regulation: Are capital requirements enough? Am. Econ. Rev. 2000, 90, 147-165. [CrossRef]

36. Delis, M.D.; Papanikolaou, N.I. Determinants of bank efficiency: Evidence from a semi-parametric methodology. Manag. Financ. 2009, 35, 260-275. [CrossRef]

37. Girardone, C.; Molyneux, P.; Gardener, E.P. Analysing the determinants of bank efficiency: The case of Italian banks. Appl. Econ. 2004, 36, 215-227. [CrossRef]

38. Mester, L.J. Efficiency in the savings and loan industry. J. Bank. Financ. 1993, 17, 267-286. [CrossRef]

39. Mester, L.J. A study of bank efficiency taking into account risk-preferences. J. Bank. Financ. 1996, 20, 1025-1045. [CrossRef]

40. Garmaise, M.J. Ties that truly bind: Noncompetition agreements, executive compensation, and firm investment. J. Law Econ. Organ. 2011, 27, 376-425. [CrossRef]

41. Boyd, J.H.; De Nicolo, G. The theory of bank risk taking and competition revisited. J. Financ. 2005, 60, 1329-1343. [CrossRef]

42. Repullo, R. Capital requirements, market power, and risk-taking in banking. J. Financ. Intermed. 2004, 13, 156-182. [CrossRef]

43. Borio, C.; Zhu, H. Capital regulation, risk-taking and monetary policy: A missing link in the transmission mechanism? J. Financ. Stab. 2012, 8, 236-251. [CrossRef] 
44. Saunders, A.; Strock, E.; Travlos, N.G. Ownership structure, deregulation, and bank risk taking. J. Financ. 1990, 45, 643-654. [CrossRef]

45. Karkowska, R. Business model as a concept of sustainability in the banking sector. Sustainability 2020, 12, 111. [CrossRef]

46. Ariss, R.T. On the implications of market power in banking: Evidence from developing countries. J. Bank. Financ. 2010, 34, 765-775. [CrossRef]

47. Schaeck, K.; Cihak, M.; Wolfe, S. Are competitive banking systems more stable? J. Money Credit. Bank. 2009, 41, 711-734. [CrossRef]

48. Caminal, R.; Matutes, C. Market power and banking failures. Int. J. Ind. Organ. 2002, 20, 1341-1361. [CrossRef]

49. Claessens, S.; Laeven, L. What drives bank competition? Some international evidence. J. Money Credit. Bank. 2004, 36, 563-583. [CrossRef]

50. Beck, T.; Demirgüç-Kunt, A.; Levine, R. Bank concentration, competition, and crises: First results. J. Bank. Financ. 2006, 30, 1581-1603. [CrossRef]

51. Berger, A.N.; Klapper, L.F.; Turk-Ariss, R. Bank competition and financial stability. J. Financ. Serv. Res. 2009, 35, 99-118. [CrossRef]

52. Bikker, J.A.; Haaf, K. Measures of competition and concentration in the banking industry: A review of the literature. Econ. Financ. Model. 2002, 9, 53-98.

53. Degryse, H.; Ongena, S. Competition and Regulation in the Banking Sector: A Review of the Empirical Evidence on the Sources of Bank Rents. In Handbook of Financial Intermediation and Banking; Thakor, A.V., Boot, A.W.A., Eds.; Elsevier: San Diego, CA, USA, 2008; pp. 483-554. [CrossRef]

54. Pampurini, F.; Quaranta, A.G. Sustainability and efficiency of the European banking market after the global crisis: The impact of some strategic choices. Sustainability 2018, 10, 2237. [CrossRef]

55. Musa, H.; Natorin, V.; Musova, Z.; Durana, P. Comparison of the efficiency measurement of the conventional and Islamic banks. Oeconomia Copernic. 2020, 11, 29-58. [CrossRef]

56. Dessaint, O.; Golubov, A.; Volpin, P. Employment protection and takeovers. J. Financ. Econ. 2017, 125, 369-388. [CrossRef]

57. Jung, D.J. Jury verdicts in wrongful termination cases. In Public Law Research Institute Report; University of California Hastings College of the Law: San Francisco, CA, USA, 1997.

58. Dertouzos, J.N. The End of Employment-at-Will: Legal and Economic Costs; RAND Corporation: Santa Monica, CA, USA, 1988; Available online: https:/ /www.rand.org/pubs/papers/P7441.html (accessed on 3 February 2021).

59. Kugler, A.D.; Saint-Paul, G. How do firing costs affect worker flows in a world with adverse selection? J. Lab. Econ. 2004, 22, 553-584. [CrossRef]

60. Bird, R.C.; Knopf, J.D. Do wrongful-discharge laws impair firm performance? J. Law Econ. 2009, 52, 197-222. [CrossRef]

61. Acharya, V.V.; Baghai, R.P.; Subramanian, K.V. Wrongful discharge laws and innovation. Rev. Financ. Stud. 2014, 27, 301-346. [CrossRef]

62. Coccorese, P. Estimating the Lerner index for the banking industry: A stochastic frontier approach. Appl. Financ. Econ. 2014, $24,73-88$. [CrossRef]

63. Yeyati, E.L.; Micco, A. Concentration and foreign penetration in Latin American banking sectors: Impact on competition and risk. J. Bank. Financ. 2007, 31, 1633-1647. [CrossRef]

64. Beck, T.; De Jonghe, O.; Schepens, G. Bank competition and stability: Cross-country heterogeneity. J. Financ. Intermed. 2013, 22, 218-244. [CrossRef]

65. Elzinga, K.G.; Mills, D.E. The Lerner index of monopoly power: Origins and uses. Am. Econ. Rev. 2011, 101, 558-564. [CrossRef]

66. Berger, A.N.; Humphrey, D.B. Measurement and efficiency issues in commercial banking. In Output Measurement in the Service Sectors; University of Chicago Press: Chicago, IL, USA, 1992; pp. 245-300.

67. Akhavein, J.D.; Berger, A.N.; Humphrey, D.B. The effects of megamergers on efficiency and prices: Evidence from a bank profit function. Rev. Ind. Organ. 1997, 12, 95-139. [CrossRef]

68. Mester, L.J. Measuring efficiency at US banks: Accounting for heterogeneity is important. Eur. J. Oper. Res. 1997, 98, 230-242. [CrossRef]

69. Bonin, J.P.; Hasan, I.; Wachtel, P. Bank performance, efficiency and ownership in transition countries. J. Bank. Financ. 2005, 29, 31-53. [CrossRef]

70. Kumbhakar, S.C.; Lovell, C.K. Stochastic Frontier Analysis; Cambridge University Press: Cambridge, UK, 2003.

71. Humphrey, D.B.; Pulley, L.B. Banks' responses to deregulation: Profits, technology, and efficiency. J. Money Credit. Bank. 1997, 1997, 73-93. [CrossRef]

72. Laeven, L.; Levine, R. Bank governance, regulation and risk taking. J. Financ. Econ. 2009, 93, 259-275. [CrossRef]

73. Kroszner, R.S.; Strahan, P.E. What drives deregulation? Economics and politics of the relaxation of banking branching restrictions. Quart. J. Econ. 1999, 104, 1437-1467. [CrossRef]

74. Stiroh, K.J.; Strahan, P.E. Competitive dynamics of deregulation: Evidence from US banking. J. Money Credit. Bank. 2003, 35, 801-828. [CrossRef]

75. Lewin, D. Dispute resolution in the nonunion firm: A theoretical and empirical analysis. J. Confl. Resolut. 1987, 31, 465-502. [CrossRef]

76. Abraham, S.E. An empirical assessment of employment-at-will: A tale of two states. Manag. Law 2004, 46, 3-19. [CrossRef] 
77. Houston, J.F.; Lin, C.; Lin, P.; Ma, Y. Creditor rights, information sharing, and bank risk taking. J. Financ. Econ. 2010, 96, 485-512. [CrossRef]

78. Roy, A.D. Safety first and the holding of assets. Econom. J. Econom. Soc. 1952, 20, 431-449. [CrossRef]

79. Jiang, T.; Levine, R.; Lin, C.; Wei, L. Bank deregulation and corporate risk. J. Corp. Financ. 2020, 60, 101520. [CrossRef]

80. Acharya, V.V.; Amihud, Y.; Litov, L. Creditor rights and corporate risk-taking. J. Financ. Econ. 2011, 102, 150-166. [CrossRef]

81. Faccio, M.; Marchica, M.-T.; Mura, R. Large shareholder diversification and corporate risk-taking. Rev. Financ. Stud. 2011, 24, 3601-3641. [CrossRef]

82. Boubakri, N.; Cosset, J.-C.; Saffar, W. The role of state and foreign owners in corporate risk-taking: Evidence from privatization. J. Financ. Econ. 2013, 108, 641-658. [CrossRef]

83. Deng, S.E.; Elyasiani, E.; Mao, C.X. Diversification and the cost of debt of bank holding companies. J. Bank. Financ. 2007, 31, 2453-2473. [CrossRef] 